\title{
Monitoring of transcriptional regulation in Pichia pastoris under protein production conditions Brigitte Gasser ${ }^{1}$, Michael Maurer ${ }^{1,2}$, Jari Rautio ${ }^{3}$, Michael Sauer ${ }^{1,2}$, Anamitra Bhattacharyya ${ }^{4}$, Markku Saloheimo ${ }^{3}$, Merja Penttilä ${ }^{3}$ and Diethard Mattanovich*1,2
}

\begin{abstract}
Address: ${ }^{1}$ University of Natural Resources and Applied Life Sciences Vienna, Department of Biotechnology, Institute of Applied Microbiology, Muthgasse 18, A-1190 Vienna, Austria, 2School of Bioengineering, University of Applied Sciences FH Campus Wien, Muthgasse 18, A-1190 Vienna, Austria, ${ }^{3}$ VTT Technical Research Centre of Finland, P.O. Box 1000, 02044 VTT, Espoo, Finland and ${ }^{4}$ Integrated Genomics, Inc., 2201 W. Campbell Park Drive, Suite 15, 606012-3547 Chicago, IL, USA

Email: Brigitte Gasser - brigitte.gasser@boku.ac.at; Michael Maurer - michael.maurer@boku.ac.at; Jari Rautio - jari.rautio@vtt.fi; Michael Sauer - michael.sauer@fh-campuswien.ac.at; Anamitra Bhattacharyya - anamitra@integratedgenomics.com; Markku Saloheimo - markku.saloheimo@vtt.fi; Merja Penttilä - merja.pentilla@vtt.fi; Diethard Mattanovich* - d.mattanovich@iam.boku.ac.at * Corresponding author
\end{abstract}

Published: 19 June 2007

BMC Genomics 2007, 8:179 doi:10.1/86/147|-2164-8-179
Received: 26 March 2007

Accepted: 19 June 2007

This article is available from: http://www.biomedcentral.com/I47I-2/64/8/179

(C) 2007 Gasser et al; licensee BioMed Central Ltd.

This is an Open Access article distributed under the terms of the Creative Commons Attribution License (http://creativecommons.org/licenses/by/2.0), which permits unrestricted use, distribution, and reproduction in any medium, provided the original work is properly cited.

\begin{abstract}
Background: It has become evident that host cells react to recombinant protein production with a variety of metabolic and intrinsic stresses such as the unfolded protein response (UPR) pathway. Additionally, environmental conditions such as growth temperature may have a strong impact on cell physiology and specific productivity. However, there is little information about the molecular reactions of the host cells on a genomic level, especially in context to recombinant protein secretion. For the first time, we monitored transcriptional regulation of a subset of marker genes in the common production host Pichia pastoris to gain insights into the general physiological status of the cells under protein production conditions, with the main focus on secretion stress related genes.

Results: Overexpression of the UPR activating transcription factor Haclp was employed to identify UPR target genes in P. pastoris and the responses were compared to those known for Saccharomyces cerevisiae. Most of the folding/secretion related genes showed similar regulation patterns in both yeasts, whereas genes associated with the general stress response were differentially regulated. Secretion of an antibody Fab fragment led to induction of UPR target genes in $P$. pastoris, however not to the same magnitude as Haclp overproduction. Overexpression of $S$. cerevisiae protein disulfide isomerase (PDII) enhances Fab secretion rates 1.9 fold, but did not relief UPR stress. Reduction of cultivation temperature from $25^{\circ} \mathrm{C}$ to $20^{\circ} \mathrm{C}$ led to a I.4-fold increase of specific product secretion rate in chemostat cultivations, although the transcriptional levels of the product genes (Fab light and heavy chain) were significantly reduced at the lower temperature. A subset of folding related genes appeared to be down-regulated at the reduced temperature, whereas transcription of components of the ER associated degradation and the secretory transport was enhanced.

Conclusion: Monitoring of genomic regulation of marker genes with the transcriptional profiling method TRAC in $P$. pastoris revealed similarities and discrepancies of the responses compared to $S$. cerevisiae. Thus our results emphasize the importance to analyse the individual hosts under real production conditions instead of drawing conclusions from model organisms. Cultivation temperature has a significant influence on specific productivity that cannot be related just to thermodynamic effects, but strongly impacts the regulation of specific genes.
\end{abstract}




\section{Background}

Heterologous protein production processes in the methylotrophic yeast Pichia pastoris became increasingly important in the last decade. Although $P$. pastoris is known as a highly efficient expression system, there is only little knowledge about the physiology and the genetics lying underneath.

Especially the production of complex proteins has turned out to have a rather low success rate (see reviews by $[1,2]$ ). Several physiological studies have demonstrated that many processes, including stress responses to environmental factors, and protein folding/aggregation and secretion are highly interrelated. Among the environmental factors influencing protein expression and secretion, $\mathrm{pH}$, osmolarity, oxygen availability and temperature appear to be particularly important (recently reviewed by [3]).

During the development of $P$. pastoris strains secreting either the human serine protease trypsinogen [4], Rhizopus oryzae lipase $[5,6]$, or the Fab fragments of the human monoclonal anti-HIV1 antibody 2F5 [7] and its antiideoptype 3H6 [8], limitations in folding and/or secretion became obvious. Using immunofluorescent staining and flow cytometry techniques we could detect intracellularly retained product, which was found to be located within the membrane fraction of cell lysates (containing compartments of the secretory pathway such as the ER and the Golgi), and a concomitant increase in the levels of intracellular BiP (binding protein), which is described as a signal molecule for unfolded protein response (UPR) (for reviews see [9-11]). On the other hand it has been shown that constitutive induction of the UPR pathway by overexpression of the transcriptional activator Hac1p can promote folding and secretion of heterologous proteins in several hosts, including Saccharomyces cerevisiae [12], Aspergillus niger var. awamori [13] and P. pastoris [7].

To our knowledge there exists no report about the regulation of gene expression upon activation of the UPR pathway in $P$. pastoris so far. We attempted to analyse these responses in more detail and to determine the possible induction of the UPR as result of the overexpression of heterologous proteins on a transcriptional level. The rapid transcriptional profiling method TRAC (transcript analysis with aid of affinity capture) that has been successfully implemented for $T$. reesei $[14,15]$ was employed in this study to monitor the levels of a subset of mRNAs coding for UPR-regulated and stress-connected genes in P. pastoris.

While a lot of data has been collected regarding the regulatory events as a reaction to temperature changes, there is not much information on the true cellular reaction particularly in context of heterologous protein expression. The optimum growth temperature for $P$. pastoris is usually defined as $28-30^{\circ} \mathrm{C}$, however, it is well established that a reduction of the temperature to e.g. $25^{\circ} \mathrm{C}$ can significantly improve recombinant protein productivity without hampering growth [16]. Jahic et al. [17] suggested that lower temperature leads to a reduced death rate, and hence a lower amount of host cell proteases in the supernatant. While this seems plausible, it should be noted that during our work we did not find such an influence of temperature on cell death at common growth temperatures [4].

Therefore a deeper understanding of the physiological and molecular links between protein folding and temperature (-adaption/-stress) appears useful.

We investigated production characteristics at $20^{\circ} \mathrm{C}$ compared to $25^{\circ} \mathrm{C}$ in chemostat cultivations expressing $2 \mathrm{~F} 5$ Fab fragment. First results indicated that specific product formation rate was 1.4 -fold higher at the lower temperature compared to steady state conditions at $25^{\circ} \mathrm{C}$. Therefore transcriptional profiling with the TRAC method was employed to study whether this increase in product secretion is a result of increased levels of UPR-regulated genes or if there are alternative mechanisms lying underneath.

\section{Results and discussion \\ Expression of more than $\mathbf{5 0}$ genes was monitored by the TRAC method in four recombinant $P$. pastoris strains and the wild type grown in various conditions}

TRAC analysis was performed in duplicates for each sample in two of the authors' laboratories in Finland (VTT) and Austria (IAM). Variation between these duplicate assays $\left(S_{M V}\right)$ was $10 \%$ on the average, and independent of signal strength as it was reported for $T$. reesei samples by [14].

For the temperature experiments, the ratio of the fluorescence intensity per ng polyA RNA (FL) in $20^{\circ} \mathrm{C}$ steady state to the $\mathrm{FL}$ in $25^{\circ} \mathrm{C}$ steady state samples was determined individually for each of the two biological replicas. The mean ratio was calculated for each probe, with the standard deviation $\left(S_{B V}\right)$ of the ratios being $21 \%$ on average. So the overall standard deviation of the temperature experiment $\left(S_{A}\right)$ adds up to $25 \%$. The probability ( $p$-values) that the FL $20^{\circ} \mathrm{C}$ does actually differ significantly from FL $25^{\circ} \mathrm{C}$ was assessed with a Student t-test.

The $P$. pastoris gene annotations in the ERGO genome database (Integrated Genomics; Chicago, IL, [18]) are derived using a number of criteria [19] including orthology to $S$. cerevisiae gene function. Consequently, all the discussion will be based on the respective descriptions (Table 1) given in the Saccharomyces Genome Database [20]. 
Table I: Functions of the markers used in TRAC analysis.

\begin{tabular}{|c|c|}
\hline & Folding \\
\hline CPR5 & Cyclophilin type peptidyl-prolyl cis-trans isomerase (ER resident) \\
\hline EROI & Pdi oxidase, protein-thiol disulfide exchange; required for oxidative protein folding in the ER \\
\hline KAR2 & $\begin{array}{l}\text { Binding protein BiP, ATPase involved in protein import into the ER, acts as a chaperone to mediate protein folding in the ER; regulates the unfolded protein } \\
\text { response }\end{array}$ \\
\hline \multirow[t]{2}{*}{ PDII } & $\begin{array}{l}\text { Protein disulfide isomerase, multifunctional protein resident in the ER lumen, essential for the formation of disulfide bonds in secretory and cell-surface } \\
\text { proteins }\end{array}$ \\
\hline & Glycosylation/ER quality control \\
\hline CNEI & Calnexin; integral membrane ER chaperone involved in folding and quality control of glycoproteins \\
\hline DFMI & ER localized derlin-like family member involved in ER stress and homeostasis; not involved in ERAD or substrate retrotranslocation \\
\hline PMT6 & Protein O-mannosyltransferase, transfers mannose from dolichyl phosphate-D-mannose to protein serine/threonine residues of secretory proteins \\
\hline ROT2 & Mannosyl-oligosaccharide glucosidase II, required for normal cell wall synthesis \\
\hline \multirow[t]{2}{*}{ SEC53 } & $\begin{array}{l}\text { Phosphomannomutase, involved in synthesis of GDP-mannose and dolichol-phosphate-mannose; required for folding and glycosylation of secretory proteins } \\
\text { in the ER lumen }\end{array}$ \\
\hline & Secretion \\
\hline $\mathrm{BMH} 2$ & 14-3-3 protein, minor isoform; binds proteins and DNA, involved in regulation of many processes including exocytosis and vesicle transport \\
\hline SARI & GTPase, GTP-binding protein of the ARF family, component of COPII coat of vesicles; required for vesicle formation during ER to Golgi protein transport \\
\hline SECI8 & ATPase required for vacuole fusion and for ER to Golgi vesicle mediated transport \\
\hline SEC3I & $\begin{array}{l}\text { Essential phosphoprotein component (pI50) of the COPII coat of secretory pathway vesicles, in complex with Sec|3p; required for ER-derived transport } \\
\text { vesicle formation }\end{array}$ \\
\hline SEC6I & Essential subunit of Sec6I complex, forms a channel for SRP-dependent protein import and retrograde transport of misfolded proteins out of the ER \\
\hline $\mathrm{SNCl}$ & Vesicle membrane receptor protein ( $v$-SNARE) involved in the fusion between Golgi-derived secretory vesicles with the plasma membrane \\
\hline \multirow[t]{2}{*}{ SSO2 } & Plasma membrane t-SNARE involved in fusion of secretory vesicles at the plasma membrane \\
\hline & ERAD (ER-associated protein degradation) \\
\hline HRDI & Ubiquitin-protein ligase (EC 6.3.2.19) required for ERAD of misfolded proteins \\
\hline \multirow[t]{2}{*}{ UBCI } & $\begin{array}{l}\text { Ubiquitin-conjugating enzyme E2 (EC 6.3.2.19) that mediates selective degradation of short-lived and abnormal proteins; plays a role in vesicle biogenesis } \\
\text { and ERAD }\end{array}$ \\
\hline & DNA repair \\
\hline RADI6 & Subunit of Nucleotide Excision Repair Factor 4 \\
\hline RAD2 & $\begin{array}{l}\text { Single-stranded DNA endonuclease, cleaves ssDNA during nucleotide excision repair to excise damaged DNA; subunit of Nucleotide Excision Repair } \\
\text { Factor } 3 \text { (NEF3) }\end{array}$ \\
\hline \multirow[t]{2}{*}{ RAD54 } & $\begin{array}{l}\text { DNA-dependent ATPase, stimulates strand exchange by modifying the topology of double-stranded DNA; involved in the recombinational repair of ds } \\
\text { breaks in DNA }\end{array}$ \\
\hline & Travers UPR \\
\hline ARL3 & GTPase of the Ras superfamily, required to recruit Arllp to the Golgi \\
\hline $\mathrm{RIBI}$ & GTP cyclohydrolase 2 \\
\hline \multirow[t]{2}{*}{ VPSI7 } & Subunit of the membrane-associated retromer complex essential for endosome-to-Golgi retrograde protein transport \\
\hline & Core metabolism \\
\hline ACSI & Acetyl-coA synthetase isoform which catalyzes the formation of acetyl-CoA from acetate and CoA \\
\hline CITI & Citrate synthase, catalyzes the condensation of acetyl coenzyme A and oxaloacetate to form citrate; the rate-limiting enzyme of the TCA cycle \\
\hline PFKI & Phosphofructokinase alpha subunit \\
\hline TALI & $\begin{array}{l}\text { Transaldolase, enzyme in the non-oxidative pentose phosphate pathway; converts sedoheptulose 7-phosphate and glyceraldehyde 3-phosphate to erythrose } \\
\text { 4-phosphate and fructose 6-phosphate }\end{array}$ \\
\hline
\end{tabular}


Table I: Functions of the markers used in TRAC analysis. (Continued)

\begin{tabular}{|c|c|}
\hline \multirow[t]{2}{*}{ TKLI } & $\begin{array}{l}\text { Transketolase, catalyzes conversion of xylulose-5-phosphate and ribose-5-phosphate to sedoheptulose-7-phosphate and glyceraldehyde-3-phosphate in the } \\
\text { pentose phosphate pathway; needed for synthesis of aromatic amino acids }\end{array}$ \\
\hline & General stress response \\
\hline BFR2 & Essential protein possibly involved in secretion; multicopy suppressor of sensitivity to Brefeldin A, homolog of LTVI (low temperature viability protein) \\
\hline CUP5 & Vacuolar ATP synthase proteolipid subunit (EC 3.6.3.14) required for vacuolar acidification and important for copper and iron metal ion homeostasis \\
\hline GCN4 & Transcriptional activator of amino acid biosynthetic genes in response to amino acid starvation \\
\hline HEMI 2 & Uroporphyrinogen decarboxylase, catalyzes the fifth step in the heme biosynthetic pathway \\
\hline HOGI & Mitogen-activated and osmosensing protein kinase, involved in osmoregulation \\
\hline IMHI & $\begin{array}{l}\text { Protein involved in vesicular transport, mediates transport between an endosomal compartment and the Golgi, contains a GRIP domain that interacts with } \\
\text { activated Arl IP-GTP to localize Imh Ip to the Golgi }\end{array}$ \\
\hline KIN2 & Serine/threonine protein kinase involved in regulation of exocytosis; localizes to the cytoplasmic face of the plasma membrane \\
\hline MSN2 & $\begin{array}{l}\text { Transcriptional activator; activated in stress conditions; binds DNA at stress response elements; response to aging, freezing, osmotic, oxidative stress and } \\
\text { glucose starvation }\end{array}$ \\
\hline \multirow[t]{2}{*}{ SNZ2/3 } & Member of a stationary phase-induced gene family, involved in pyridoxine and thiamin biosynthesis \\
\hline & Thioredoxin \\
\hline TRRI & $\begin{array}{l}\text { Cytoplasmic thioredoxin reductase, key regulatory enzyme that determines the redox state of the thioredoxin system, which acts as a disulfide reductase } \\
\text { system and protects cells against both oxidative and reductive stress }\end{array}$ \\
\hline \multirow[t]{2}{*}{ TSAI } & Thioredoxin peroxidase, reduces reactive oxygen, nitrogen and sulfur species using thioredoxin as hydrogen donor \\
\hline & Amino acid synthesis \\
\hline ARGI & Arginosuccinate synthetase, catalyzes the formation of L-argininosuccinate from citrulline and L-aspartate in the arginine biosynthesis pathway \\
\hline ARO4 & 3-deoxy-D-arabino-heptulosonate-7-phosphate (DAHP) synthase, catalyzes the first step in aromatic amino acid biosynthesis \\
\hline \multirow[t]{2}{*}{ GLTI } & NAD(+)-dependent glutamate synthase, synthesizes glutamate from glutamine and alpha-ketoglutarate \\
\hline & Glutathione \\
\hline GLRI & Glutathione oxidoreductase, converts oxidized glutathione to reduced glutathione \\
\hline \multirow[t]{2}{*}{ GSH2 } & $\begin{array}{l}\text { Glutathione synthetase, catalyzes the ATP-dependent synthesis of glutathione (GSH) from gamma-glutamylcysteine and glycine; induced by oxidative stress } \\
\text { and heat shock }\end{array}$ \\
\hline & Cytosolic hsps \\
\hline HSPI2 & $\begin{array}{l}\text { Plasma membrane localized protein that protects membranes from desiccation; induced by heat shock, oxidative stress, osmostress, stationary phase entry, } \\
\text { glucose depletion, regulated by the HOG and Ras-Pka pathways }\end{array}$ \\
\hline HSP90/82 & $\begin{array}{l}\text { Cytoplasmic chaperone (Hsp90 family), required for the activation of many key cellular regulatory and signaling proteins, like kinases and transcription } \\
\text { factors }\end{array}$ \\
\hline SSA4 & $\begin{array}{l}\text { Cytoplasmic member of the HSP70 family; highly induced upon stress; plays a role in SRP-dependent cotranslational protein-membrane targeting and } \\
\text { translocation }\end{array}$ \\
\hline \multirow[t]{2}{*}{$\mathrm{SSEI} / 2$} & ATPase that is a component of the Hsp90 chaperone complex; binds unfolded proteins; member of the HSP70 family; localized to the cytoplasm \\
\hline & Ribosomes \\
\hline RPL3 & Protein component of the large (60S) ribosomal subunit \\
\hline \multirow[t]{2}{*}{ RPS23B } & Ribosomal protein 28 (rp28) of the small (40S) ribosomal subunit \\
\hline & Heterologous protein \\
\hline LC & Fab light chain \\
\hline $\mathrm{HC}$ & Fab heavy chain \\
\hline
\end{tabular}

\footnotetext{
Functions of the S. cerevisiae homologs of the P. pastoris gene markers (adapted from Saccharomyces Genome Database [20]) assigned in functional categories.
} 


\section{Effect of Hacl-overexpression on the regulation of marker genes in $\mathbf{P}$. pastoris}

As the active form of $P$. pastoris Hac1p is not identified yet, the $S$. cerevisiae homolog was used. Cross species functionality of Hac1p has been demonstrated between $S$. cerevisiae and $P$. pastoris [7], and $T$. reesei respectively [12]. Therefore, TRAC analysis of shake flask cultivations of $P$. pastoris strains co-overexpressing $S$. cerevisiae UPR-transcription factor Hac1p was applied to identify UPR-targets in $P$. pastoris and the responses were compared to those observed in S. cerevisiae [21]. In that study, S. cerevisiae UPR target genes were induced by dithiothreitol (DTT) and tunicamycin, two agents known to interfere with protein folding in the ER.

Both P. pastoris GS115, and the protease deficient strain SMD1168, containing S. cerevisiae HAC1 were analysed, and no difference could be seen in the regulation of the marker genes included in our analysis. Therefore a mean value of these two experiments was compared to untransformed X33 as control strain.

More than a 2-fold induction of genes like KAR2 (BiP, 5fold), PDI1 (protein disulfide isomerase, 3-fold), ERO1 (Pdi oxidase, 2-fold) and SEC61 (part of translocon complex into the ER, 2-fold) was observed in $P$. pastoris (Figure 1A), analogous to the UPR response described for $S$. cerevisiae[21]. Strong enhancement in the transcription of genes involved in the ER quality control and glycosylation such as CNE1 (calnexin), ROT2 (glucosidase II) and SEC53 (phosphomannomutase) was predominant in $P$. pastoris, while components of the ER-associated protein degradation (ERAD) represented by HRD1 and UBC1 showed a more consistent upregulation, as compared to $S$. cerevisiae. Also the down-regulation of core metabolism genes such as PFK1 (glycolysis), CIT1 (TCA cycle), GLT1 and ARO4 (amino acid biosynthesis) and ribosomal genes (RPS23B, RPL3) during UPR induction seems to be a common feature for both of the yeasts (Figure 1D), while the transcription of other genes is differentially regulated between the two organisms.

Remarkably, the oppositional regulation of the two general stress markers GCN4 and MSN2 was noticed. While GCN4 was upregulated in P. pastoris but down-regulated in S. cerevisiae, MSN2 behaved the other way round (Figure $1 \mathrm{~B}, \mathrm{C}$ ). Induction of GCN4 transcription in response to DTT treatment or heterologous protein expression was reported for T. reesei, as well as enhanced expression levels of some of its putative target genes related to amino acid biosynthesis, among them GLT1, ARG1, ARO4 [22]. On the contrary to $T$. reesei we can not see a similar behaviour of the amino acid biosynthesis genes included in our marker set, as levels of GLT1 (glutamate biosynthesis) are strongly reduced, while ARG1 (arginine) transcription is

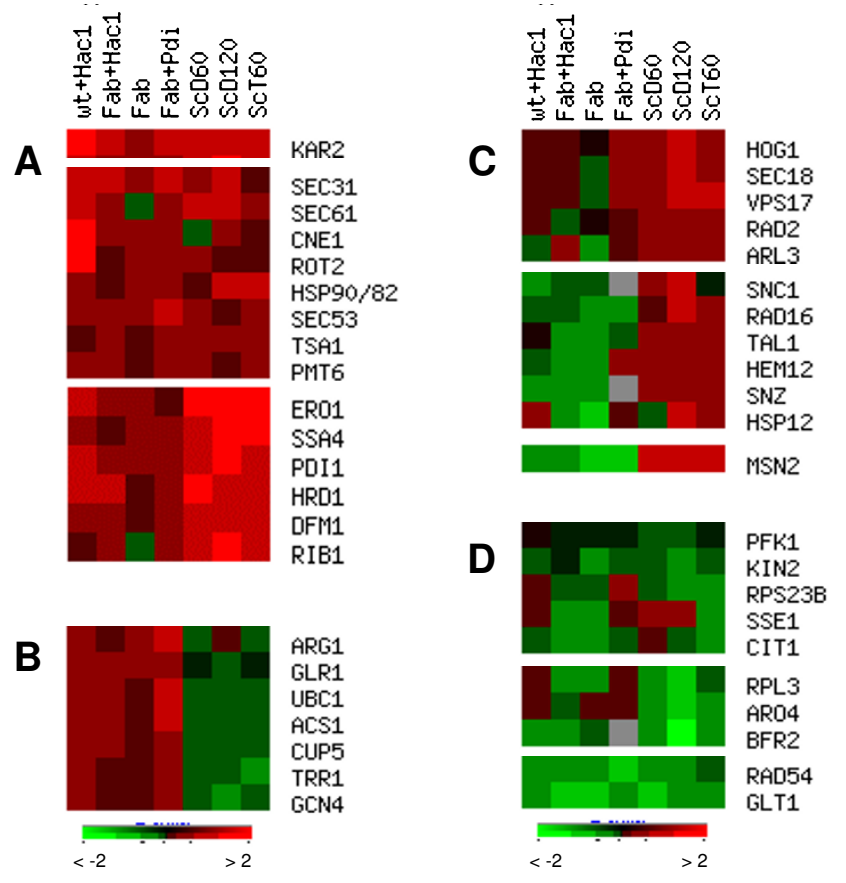

\section{Figure I}

Comparison of the UPR response in $P$. pastoris and $S$. cerevisiae. Abbreviations for $P$. pastoris strains are explained in Table 3, all data are derived from comparison to the wild type. Data from $S$. cerevisiae were taken from [2I], where UPR was induced with DTT or tunicamycin. ScD60 (treatment with DTT after $60 \mathrm{~min}$ ); ScDI 20 (treatment with DTT after $120 \mathrm{~min}$ ); ScT60 (treatment with tunicamycin after 60 $\mathrm{min}$ ), all compared to a non-treated culture. Cluster analysis was made using EPClust [47], Euklidian distance with complete linkage. Subclusters are shown for the following: A: genes induced in both yeasts; B: upregulated in P. pastoris, down-regulated in $S$. cerevisiae; C: down-regulated to unchanged in $P$. pastoris, upregulated in S. cerevisiae; $D$ : reduced in both yeasts. Subclusters of genes that are unchanged in both organisms are not displayed. The brightest colouring corresponds to the $\log _{2}$ regulation $\geq \pm 2$.

enhanced. Recently, Patil and coworkers [23] described activation of Gcn4p by ER stress and suggested that it acts as an essential transcription factor for the UPR together with or downstream of Hac1p. A link between ER stress and oxidative stress was established in mammalian cells, where the expression of the GCN4 homolog ATF4 regulates glutathione biosynthesis and thereby protects the cells against the accumulation of reactive oxygen species deriving from the oxidative protein folding machinery in the ER and the ERAD [24]. Both glutathione (GLR1) and thioredoxin (TRR1, TSA1) related genes show higher expression levels in the Hac1p-overproducing strain compared to the control strain in $P$. pastoris (all displayed in Figure 1A, B). 
No direct connection between the general environmental response transcriptional activator Msn2 [25] and UPR regulation has been reported so far. Most significantly, a fraction of genes that are correlated to general stress response appears to be induced in $S$. cerevisiae but remains unchanged to down-regulated in $P$. pastoris along with Msn2 (Figure 1C). Among them Hem12 serves as a marker for oxygen availability, Rad16 and Rad2 belong to the DNA repair mechanism, Arl3 and Vps17 are connected to the transport between the endosomal compartment and the Golgi, while Snooze genes are members of stationary phase related gene family and reported to be induced both by pyridoxal and thiamin depletion [26]. The involvement of the HOG1 (high osmolarity glycerol) pathway in more general environmental stress responses was discussed in [27], and can be connected to the regulation of many other genes including HSP12 (all displayed in Figure 1C).

\section{Induction of the unfolded protein response by heterologous protein secretion}

In order to elucidate the behaviour of genes typically known to be under UPR-regulation additionally to other stress-associated markers in recombinant protein producing cells, $P$. pastoris strains secreting the 2F5 antibody fragment under control of the GAP promoter were examined and their response was compared to the Hac1p-overproducing strains in figure 2.

TRAC analysis of these cultures revealed that production of 2F5 Fab actually induces genes identified as UPR-targets before. Genes such as KAR2, PDI1, ROT2, ERO1, Calnexin, SEC31, and SEC53 are significantly upregulated, although not to the same magnitude as in the Hac1p-overproducing strains. Additionally, expression levels of genes belonging to the core metabolism (GLT1, CIT1), general stress response (MSN2, SNZ) and ribosomal components (RPL3) showed down regulation in the Fab-expressing strain, as has been observed in the strain constitutively overexpressing the UPR transcription factor Haclp. Out of 20 genes detected to be under Hac1p-specific activation, 11 appeared to be up-regulated in the Fab-expressing strain, and all of the three genes identified to be under Hac1p-dependent down-regulation showed lower transcription levels also in the recombinant strain. No explanation can be given for the divergent regulation pattern of HSP12.

Previous transcriptional studies in Aspergillus nidulans and T. reese $i$ are in agreement with our finding that changes in mRNA levels are more subtle and specific in recombinant protein producing strains than in cultures treated with secretion blockers like DTT, tunicamycin and Brefeldin A or strains with constitutively activated UPR $[28,22]$.

\section{No reduction of UPR activation due to PDI I overexpression}

Furthermore, folding engineered strains constitutively coproducing S. cerevisiae Pdi1 or Hac1p, which were identified to increase 2F5 Fab secretion 1.9- and 1.3- fold, respectively [7], were subjected to TRAC analysis and compared to their parental strain. The results are displayed in figure 3.

Out of 20 transcripts established to be up-regulated in response to UPR activation, 12 can be found to be at least 1.5 -fold induced in the Hac1p-expressing strain as compared to the strain expressing only $2 \mathrm{~F} 5 \mathrm{Fab}$ (Figure $3 \mathrm{~A}$ ). The genes detected to be down-regulated in the Haclpoverexpressing strain as compared to the wild-type show no regulation here as they also have significantly lower expression levels in the Fab expressing strain (compared to the wild type).

Interestingly, when analysing the PDI1-overexpressing strains (Figure 3B), we found that most genes seem to be unaffected by PDI1 overexpression at a transcriptional level, although 2F5 Fab secretion rates are enhanced under these conditions. Unlike Xu et al. [29] who reported a relief of UPR induction caused by recombinant protein expression when PDI1 is overexpressed in S. cerevisiae, our results suggest that overexpression of $S$. cerevisiae PDI1 does not alleviate UPR stress in P. pastoris. Thus it is likely that there are other mechanisms easing the secretion of the antibody fragments. Interestingly, there are several genes belonging to the vesicular protein transport system involved in ER to Golgi and Golgi to plasma membrane transport (SAR1, SEC18, SEC31, SSO2), and the ERAD among the genes most induced (although less than 1.5fold) in the Pdilp-coproducing strain, however, some genes connected to Pdi1 like ERO1 and the cyclophilin type peptidyl-prolyl isomerase CPR5 have significantly lower transcription levels in this strain.

\section{Influence of cultivation temperature on protein secretion rates and transcriptional response}

After monitoring the transcriptional effects specific to UPR induction on a chosen gene set in $P$. pastoris, we intended to uncover the transcriptional responses occurring in cells under production conditions. The particular interest of this collaborative work was to study the interactions between cellular responses triggered by protein overproduction (with particular emphasis on protein synthesis, folding and secretion and related stress responses), and different cultivation temperatures as an example for environmental (cultivation process) conditions.

As our usual production processes were set up at $25^{\circ} \mathrm{C}[4]$, we intended to investigate production characteristics at an even lower, but still feasible temperature of $20^{\circ} \mathrm{C}$. Two 

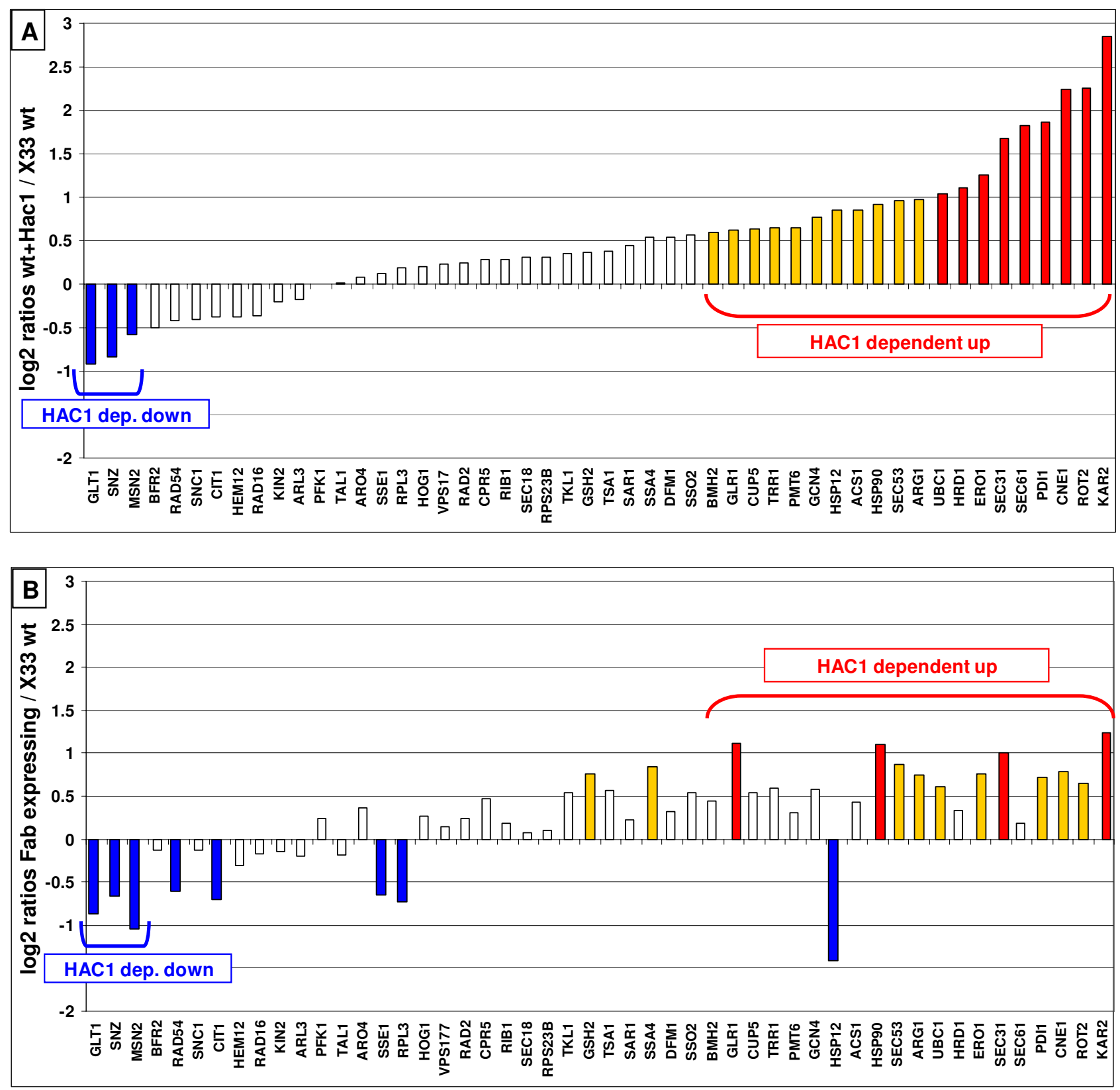

Figure 2

UPR regulation in P. pastoris. A: Log $_{2}$ ratio of Haclp-overproducing strains compared to the wild type, Haclp-dependend up- or downregulatated genes are highlighted; B: Log $_{2}$ ratio of cultures producing $2 \mathrm{~F} 5 \mathrm{Fab}$ under control of the GAP promoter compared to the wild type, in the same order as A. Red bars: change in transcript up > 2-fold; yellow bars: up > 1.5 fold; white bars: unchanged; blue bars: down > 1.5 fold.

independent chemostat cultivations of a $P$. pastoris strain secreting 2F5 Fab under control of the GAP promoter have been conducted, with a dilution rate of $\mathrm{D}=0.043 \mathrm{~h}^{-1}$ and glucose as carbon source, one starting at $25^{\circ} \mathrm{C}$ and shifted to $20^{\circ} \mathrm{C}$ after 5 volume changes, the other vice versa. In both experiments the biomass reached approx. $25 \mathrm{~g} / \mathrm{L}$ YDM at both temperatures, however, Fab secretion levels were elevated on average 1.4-fold at the lower temperature (Table 2). The difference was determined to be highly significant by a Student t-test $(\mathrm{p}=0.00966)$. 

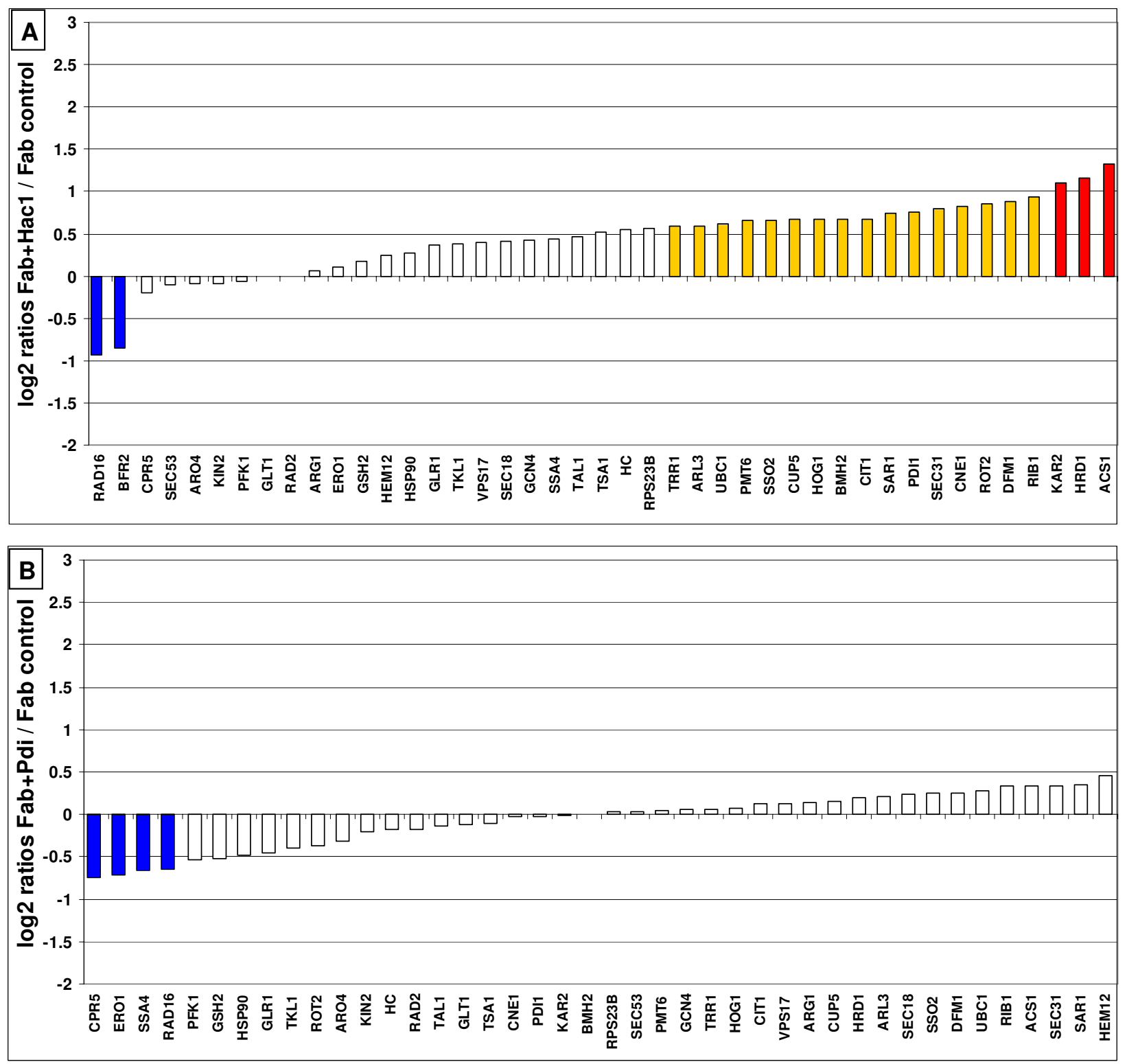

Figure 3

Effect of engineered folding factors on the transcriptional level. A: Constitutively UPR induced $2 F 5$ Fab producing SMDI 68 (Fab+Hacl) compared to its control strain (containing only the Fab expression cassette). B: $2 \mathrm{~F} 5 \mathrm{Fab}$ producing SMDI 68 co-expressing S. cerevisiae PDII compared to the control strain. Both diagrams are ordered from the lowest to the highest $\log _{2}$ ratio. Colour legend as in figure 2.

Similar improvement of secretion of a single chain fragment (scFv) upon a reduction to $20^{\circ} \mathrm{C}$ (compared to 30 and $37^{\circ} \mathrm{C}$ ) was reported for S. cerevisiae [30], while Li et al. [16] described a positive effect of lower temperature $\left(23^{\circ} \mathrm{C}\right)$ on growth and viability during the expression of a herring antifreeze protein in $P$. pastoris, but it should be considered that their data result from shake flasks only. In our experiments, viability remained constantly high (> $98.5 \%$ ) at both temperatures examined.
Although the transcriptional levels of the product genes (2F5 Fab light and heavy chain) were reduced at $20^{\circ} \mathrm{C}$ compared to cultivation on $25^{\circ} \mathrm{C}$ (Figure 4), specific productivity of the 2F5 Fab protein was significantly increased during the chemostat process at lower temperature (1.4-fold on average). Several genes related to protein targeting to the ER and folding (SSA4, SEC53, KAR2, ERO1) and core metabolism genes can be found among the genes down-regulated at $20^{\circ} \mathrm{C}$. Transcription of genes 
Table 2: Chemostat cultivations of $P$. pastoris $X 33$ producing 2 F5 Fab utilizing the GAP promoter at two different temperatures.

\begin{tabular}{|c|c|c|c|}
\hline & YDM [g/L] & product [mg/L] & $q_{\mathrm{P}}\left[\mathrm{mg} \mathrm{g}^{-1} \mathrm{~h}^{-1}\right]$ \\
\hline \multicolumn{4}{|l|}{ Chemostat I } \\
\hline $25^{\circ} \mathrm{C}$ & 25.1 & 5.3 & 0.0079 \\
\hline $20^{\circ} \mathrm{C}$ & 23.2 & 7.4 & 0.0122 \\
\hline \multicolumn{4}{|l|}{ Chemostat 2} \\
\hline $20^{\circ} \mathrm{C}$ & 27.0 & 7.0 & 0.0091 \\
\hline $25^{\circ} \mathrm{C}$ & 24.8 & 5.2 & 0.0074 \\
\hline mean ratio $20^{\circ} \mathrm{C} / 25^{\circ} \mathrm{C}$ & 1.0 & 1.4 & 1.4 \\
\hline
\end{tabular}

Chemostat I was cultivated at $25^{\circ} \mathrm{C}$ first and temperature was lowered to $20^{\circ} \mathrm{C}$ after 5 volume changes, chemostat 2 was performed vice versa. Steady state conditions were assumed after 5 volume changes. Biomass (YDM), $2 \mathrm{~F} 5 \mathrm{Fab}$ concentration (product) and specific production rate $q_{\mathrm{P}}$ are given for both cultivations, additionally to the mean ratio of $20^{\circ} \mathrm{C}$ to $25^{\circ} \mathrm{C}$ for each of these parameters.

involved in the regulation of vesicular transport, exocytosis, ER-associated protein degradation as well as markers for response to oxidative and hyperosmotic stress was enhanced in comparison to $25^{\circ} \mathrm{C}$ steady state (see Figure $4)$.

Since there was strong evidence that (partially) unfolded product was retained inside the cells during fed batch cultivations $[4,7]$, thus leading to an upregulation of the UPR marker protein $\mathrm{BiP}$, we investigated the behaviour of these proteins also in the chemostat. According to immunofluorescent staining and flow cytometer analysis intracellular product levels (Fab light chain and heavy chain fragment) are increased at the lower temperature (Figure 5), on the contrary to BiP which shows the same trend as its transcript KAR2. Our hypothesis is that at the lower temperature less folding stress is provoked by the native Pichia proteins and consequently less cumulative pressure is imposed on the folding machinery. Therefore no induction of BiP transcription could be seen at the lower temperature although more of the recombinant protein was accumulated intracellularly.

ER associated protein degradation is a process detecting misfolded proteins in the ER and redirecting them to the translocon for retranslocation to the cytosol, where they are subjected to proteasomal degradation. Additionally, excess subunits of multimeric proteins that are unable to assemble are degraded through the ERAD mechanism [31]. With HRD1, coding for an ubiquitin-protein ligase, that is able to recruit ubiquitin-conjugating enzymes such as the gene product of $U B C 1$ next to the translocon pore complex (Sec61p being an essential subunit of the complex), three essential components of the ERAD pathway are up-regulated in correlation to higher protein secretion rates. One could speculate that increased ERAD activity at lower temperature might lead to degradation of excess $\mathrm{HC}$, thus reducing ER stress conditions and therefore leading to better secretion. However, no evidence is given that excess HC is degraded, as intracellular product levels are increased at the lower temperature. No components of the proteasomal system have been included into the study.

All analysed members of the Hsp70-family of chaperones are less transcribed at the lower temperature. This performance can be explained in concordance with their stringent requirement in conditions of heat shock. Together BiP/Kar2p and the Ssa-proteins (ER-localized and cytosolic hsp70, respectively) are required for the import of nascent polypeptides through the translocon into the ER lumen, where $\mathrm{BiP}$ is acting as a chaperone. BiP is also necessary for the degradation of misfolded proteins. However, so far no essential role of the Ssa-proteins in the retrograde transport of misfolded soluble proteins during ERAD has been identified [32,33]. The chaperonines of the Sse/Hsp110 subclass of the Hsp70 family, that are encoded by SSE1 and SSE2, assist in folding by binding to nascent peptides and holding them in a folding-competent state, however, they can not actively promote folding reactions.

Other transcripts significantly down-regulated at the lower temperature belong to the phosphomannomutase SEC53, the protein O-mannosyltransferase PMT6, both being involved in glycosylation of secretory proteins as well as to the ER resident thiol-oxidase ERO1 (acting as a specific oxidant for protein disulfide oxidase). The product of the IMH1/SYS3 gene is a member of the peripheral membrane Golgins involved in vesicular transport between the late Golgi and a prevacuolar, endosome-like compartment [34].

The transcriptional activator of amino acid biosynthetic genes in response to amino acid starvation GCN4 is downregulated 1.4 -fold at $20^{\circ} \mathrm{C}$ steady state levels. Although it might be speculated that a lower concentration of Gcn 4 can lead to lower transcription of amino acid biosynthesis genes, in our experiment only GLT1 (glutamate synthase) is significantly reduced. The pathways for aromatic amino acids (with ARO4 as marker) and arginine biosynthesis (ARG1) tend to be downregulated. 


\begin{tabular}{|c|c|c|c|}
\hline $\begin{array}{l}\text { gene } \\
\text { name }\end{array}$ & $\begin{array}{c}\text { log2 average ratio } \\
\text { expression } \\
20^{\circ} \mathrm{C} / 25^{\circ} \mathrm{C}\end{array}$ & $p$-value & $\begin{array}{c}\text { significance } \\
\text { level }^{\text {a }}\end{array}$ \\
\hline SSA4 & -0.893 & 0.006 & $* \star * *$ \\
\hline SEC53 & -0.717 & 0.001 & $\star * *$ \\
\hline RAD16 & -0.601 & 0.162 & \\
\hline KAR2 & -0.549 & 0.042 & ** \\
\hline GLT1 & -0.512 & 0.010 & ** \\
\hline ERO1 & -0.503 & 0.839 & \\
\hline GCN4 & -0.483 & 0.152 & \\
\hline LC & -0.440 & 0.001 & $* * *$ \\
\hline $\mathrm{HC}$ & -0.426 & 0.046 & $* *$ \\
\hline PMT6 & -0.392 & 0.221 & \\
\hline SSE1 & -0.384 & 0.054 & * \\
\hline TAL1 & -0.339 & 0.093 & * \\
\hline ARL3 & -0.315 & 0.501 & \\
\hline ARG1 & -0.273 & 0.622 & \\
\hline IMH1 & -0.255 & 0.049 & ** \\
\hline ARO4 & -0.252 & 0.571 & \\
\hline MSN2 & -0.243 & 0.055 & * \\
\hline TKL1 & -0.238 & 0.014 & ** \\
\hline RAD54 & -0.223 & 0.149 & \\
\hline CPR5 & -0.153 & 0.282 & \\
\hline BFR2 & -0.147 & 0.478 & \\
\hline CIT1 & -0.125 & 0.010 & ** \\
\hline SEC31 & -0.116 & 0.661 & \\
\hline ACS1 & -0.102 & 0.195 & \\
\hline CNE1 & -0.080 & 0.096 & * \\
\hline GSH2 & -0.028 & 0.962 & \\
\hline DFM1 & -0.001 & 0.818 & \\
\hline KIN2 & 0.045 & 0.834 & \\
\hline HEM12 & 0.053 & 0.807 & \\
\hline SAR1 & 0.058 & 0.531 & \\
\hline VPS17 & 0.058 & 0.817 & \\
\hline RIB1 & 0.065 & 0.742 & \\
\hline SEC18 & 0.065 & 0.683 & \\
\hline PFK1 & 0.093 & 0.721 & \\
\hline HSP90/82 & 0.094 & 0.331 & \\
\hline RPL3 & 0.104 & 0.007 & $* \star *$ \\
\hline CUP5 & 0.141 & 0.693 & \\
\hline HSP12 & 0.146 & 0.465 & \\
\hline HRD1 & 0.175 & 0.037 & ** \\
\hline PDI1 & 0.202 & 0.164 & \\
\hline SSO2 & 0.203 & 0.094 & * \\
\hline GLR1 & 0.206 & 0.086 & * \\
\hline SNZ & 0.231 & 0.136 & \\
\hline ROT2 & 0.245 & 0.750 & \\
\hline TRR1 & 0.290 & 0.017 & ** \\
\hline BMH2 & 0.292 & 0.072 & * \\
\hline TSA1 & 0.343 & 0.036 & ** \\
\hline RAD2 & 0.403 & 0.019 & ** \\
\hline HOG1 & 0.420 & 0.207 & \\
\hline RPS23B & 0.501 & 0.065 & * \\
\hline UBC1 & 0.517 & 0.007 & *** \\
\hline SEC61 & 0.558 & 0.006 & *** \\
\hline SNC1 & 0.666 & 0.027 & ** \\
\hline
\end{tabular}

Figure 4

Comparison of marker genes expression of 2F5 producing $\boldsymbol{P}$. pastoris during steady state conditions. Log 2 ratios of the average gene expression between $20^{\circ} \mathrm{C}$ and $25^{\circ} \mathrm{C}$ in chemostat cultivation $\left(D=0.043 \mathrm{~h}^{-1}\right)$. Genes with ratios exceeding \pm one standard deviation (SD) are marked in light blue, \pm two SD in yellow and \pm three SD in green. The $p$-value $\left(\chi^{2}\right.$-test) is given for each individual marker gene. (a) *** significance level $p \leq 0.0$ I; ** significance level $p \leq 0.05$; $*$ significance level $p \leq 0$. I 


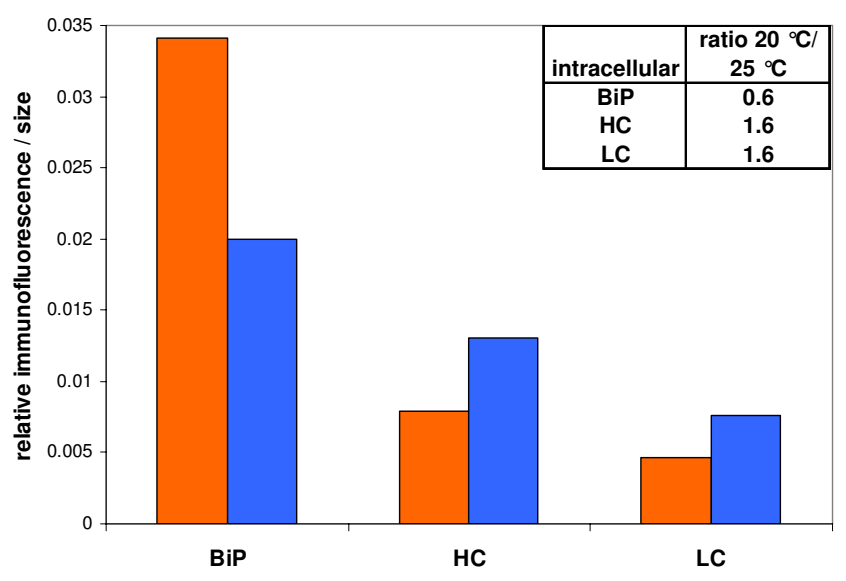

\section{Figure 5}

Intracellular product retention and BiP development analysed by immunofluorescent staining and flow cytometer analysis during cultivation at two different temperatures. Orange bars: relative fluorescence intensities per cell size obtained at $25{ }^{\circ} \mathrm{C}$ steady state; Blue bars: 20 ${ }^{\circ} \mathrm{C}$ steady state. BiP: intracellular signals for the UPR marker BiP/Kar2p (detected with anti-Grp78/BiP specific IgG). HC: intracellular signals for Fab heavy chain (obtained with anti-hFab specific lgG); LC: intracellular signals for light chain (analyzed with anti-kappa light chain $\lg G$ ).

Also the pentose phosphate shunt (represented by the genes for transaldolase TAL1 and transketolase TKL1) and the transcription of citrate synthase (CIT1) - the rate-limiting enzyme of the TCA cycle - are less active at $20^{\circ} \mathrm{C}$. This reduction in transcriptional activity of the core metabolism is a likely explanation for the reduced mRNA levels of the product genes (LC and HC), which are under control of the glycolytic GAP (glyceraldehyde 3-phosphate dehydrogenase) promoter. Essentially the same regulation pattern of amino acid biosynthesis genes and core metabolism genes was observed in a non-expressing control strain cultivated under the same conditions (data not shown). Interestingly, the transcript levels of the ribosomal proteins (RPL3, RPS23) are raised in both the Fab expressing and the non-expressing strain at $20^{\circ} \mathrm{C}$.

Unlike the general transcriptional activator in response to different stresses, MSN2, which shows reduced transcription, the genes coding for the key regulatory enzymes of both the cell redox homeostasis (thioredoxin reductase TRR1, thioredoxin peroxidase TSA1, glutathione oxidoreductase GLR1) and osmoregulation (mitogen-activated protein (MAP) kinase HOG1) are induced at the lower temperature. This seems to be a more general effect of the reduced temperature as the same regulation pattern can be observed in the P. pastoris control strain cultivated under the same conditions (data not shown). Recently, activation of the HOG pathway upon a downshift in tempera- ture $\left(30\right.$ to $\left.12^{\circ} \mathrm{C}\right)$ was monitored in S. cerevisiae, whereas in Schizosaccharomyces pombe the Sty1p MAP-kinase (the Hog1p homolog) lead to the activation of several coldinduced genes [35,36]. These authors conclude that the HOG pathway is regulated by changes in membrane fluidity, and that the downward shift in temperature results in the accumulation of glycerol in the yeast cells, while having no major effect on cell viability. Furthermore an increase in intracellular hydrogen peroxide and subsequent induction of anti-oxidant genes was revealed in response to a temperature downshift from 30 to $10^{\circ} \mathrm{C}$ in $S$. cerevisiae [37]. These results suggest that the cells are subjected to (mild) oxidative stress after cultivation in a low temperature environment, a phenomenon also shared with plants like Arabidopsis thaliana [38].

Also the transcript of another regulatory enzyme, the 143-3 protein Bmh2, is elevated at the lower temperature, at which higher rates of secretion were observed. 14-3-3 proteins, encoded by $B M H 1$ and $B M H 2$, were identified to participate in multiple steps of vesicular trafficking, especially in protein exit from the ER, forward trafficking of multimeric cell surface membrane proteins [39] as well as in retrograde transportation within the Golgi apparatus. In $S$. cerevisiae the induction of $B M H 1$ has been reported to reduce transcription of folding related genes such as SSA1/2, ERO1, HSP 82, KAR2 and CPR5 upon a shift from $37^{\circ} \mathrm{C}$ to $25^{\circ} \mathrm{C}$ [27], which may also be the case in our experiments.

The yeast syntaxin homologs Sso1 and Sso 2 are necessary for the fusion of secretory vesicles to the plasma membrane by acting as target (t-SNARE) for the vesicle membrane receptor protein ( $\mathrm{v}$-SNARE) Snc1. Both transcripts were identified to be up-regulated at the reduced temperature under production conditions.

Two genes belonging to the DNA damage response show significantly altered expression upon the temperature reduction; however, the DNA endonuclease (RAD2) is induced while RAD16 is down-regulated. Detailed functions of proteins involved in the nucleotide excision repair in yeasts are reviewed by [40], however, their connection to cultivation temperature or protein secretion remains elusive.

Generally, the reduction of temperature from $25^{\circ} \mathrm{C}$ to $20^{\circ} \mathrm{C}$ does not trigger a transcriptional reaction as definite as the overproduction of the UPR transcription factor Hac1p. As displayed in Figure 4, lowering temperature leads to a regulation pattern that is partially divergent from the UPR specific regulation, with a special discrepancy of single genes such as the HSPs. Interestingly, genes of the core metabolism, amino acid biosynthesis and ribosome biosynthesis, as well as redox and osmotic stress 
Table 3: Summary of all the P. pastoris strains used in this work.

\begin{tabular}{|c|c|c|c|}
\hline Parental strain & Product genes & Engineered folding factor & Abbreviation \\
\hline$\times 33$ & & & wild type (wt) \\
\hline GSII5 & & $\mathrm{HACl}$ & $w t+\mathrm{Hacl}$ \\
\hline SMDII68 & & $\mathrm{HACl}$ & \\
\hline SMDII68 & 2F5 Fab & & Fab (control) \\
\hline SMDII68 & 2F5 Fab & $\mathrm{HACl}$ & $\mathrm{Fab}+\mathrm{Hacl}$ \\
\hline SMDII68 & $2 \mathrm{~F} 5 \mathrm{Fab}$ & PDII & $\mathrm{Fab}+\mathrm{Pdi}$ \\
\hline$\times 33$ & 2F5 Fab & & for chemostat \\
\hline
\end{tabular}

GSII 5 is a histidin auxotrophic $P$. pastoris strain, $X 33$ is a histidin prototrophic revertant, and SMDII 68 is deleted for the vacuolar protease pep4. All expressing strains carry both the 2F5 Fab light chain gene and the heavy chain fragment under control of the GAP promoter, with the $S$. cerevisiae mating factor alpha leader as secretion signal. The folding factor engineered strains were transformed with the S. cerevisiae PDII or the induced form of Haclp under control of the GAP promoter within the HIS4 locus.

response, were regulated similarly in the Fab-expressing $P$. pastoris strain and a non-expressing control strain. On the other hand, genes belonging to the protein secretory pathway remained unchanged in the control strain, while being significantly regulated in the Fab expressing strain.

Two regulation patterns common to adaptation upon temperature changes were identified also to be conserved in P. pastoris. It becomes obvious that the effects caused upon temperature reduction are not ostensibly UPR dependent, but that this regulation is overlapped by alternative (yet unidentified) mechanisms of regulation leading to the final enhancement of antibody fragment secretion.

\section{Conclusion}

Our results indicate the importance of monitoring transcriptional regulations during recombinant protein production processes in real production strains instead of model organisms, even if there are no DNA microarrays available. The transcriptional profiling method TRAC proved to be a valuable tool to analyse genomic responses of a subset of marker genes in $P$. pastoris, and to compare them to those observed in S. cerevisiae. Upon UPR induction a lot of markers showed similar transcriptional regulation in both yeasts, however, a significant fraction of transcript levels of genes belonging to general stress response are behaving in an opposite way. Both the effects of S. cerevisiae Hac1p and Pdi1 overexpression in P. pastoris was studied, additionally to the responses induced by secretion of 2F5 Fab antibody fragment.

Interactions between growth temperature as an example for environmental conditions and specific productivity could be revealed at a transcriptional level. Reduction in temperature led to increased product secretion rates, which are the result of complex regulatory mechanisms and not only influenced by thermodynamic differences in protein folding. Common transcriptional responses to reduced temperature such as induction of genes related to oxidative and osmotic stresses are overlapped by responses to recombinant protein production such as the UPR and the ERAD. Especially the enhanced transcription of components of the secretory pathway became obvious under conditions of higher protein secretion. It is tempting to speculate that at lower temperature a reduced amount of folding stress is imposed on the cells, consequently leading to a higher rate of correctly folded product.

\section{Methods \\ Strains and vectors}

GS115 is a histidin auxotrophic $P$. pastoris strain, X33 is its respective histidin prototrophic revertant, and SMD1168 is deleted for the vacuolar protease pep4. The construction of $P$. pastoris strain X33 containing both the 2F5 Fab light and heavy chain genes under control of the constitutive GAP (glyceraldehyde-3-phosphate dehydrogenase) promoter, with the $S$. cerevisiae alpha-mating factor signal sequence for secretion, was described in [7]. Similarly, the folding factor engineered $P$. pastoris strains SMD1168 constitutively overexpressing either $S$. cerevisiae PDI1 or the induced form of Hac1p additionally to the Fab or the respective control strains were characterized in [7]. For the evaluation of UPR specific induction in $P$. pastoris, both a SMD1168 and a GS115 were transformed with the UPR transcription factor Hac1p from S. cerevisiae, without containing the genes for the Fab. The untransformed $P$. pastoris strain X33 was used for wild type comparison. A summary of all the strains used in this study can be found in Table 3.

\section{Shake flask cultures}

$5 \mathrm{~mL}$ YP-medium (10 g/L yeast extract, $20 \mathrm{~g} / \mathrm{L}$ peptone) containing $20 \mathrm{~g} / \mathrm{L}$ glucose were inoculated with a single colony and grown overnight at $30^{\circ} \mathrm{C}$. Aliquots of these cultures corresponding to a final $\mathrm{OD}_{600}$ of 0.6 were transferred to $10 \mathrm{~mL}$ main culture medium (per liter: $10 \mathrm{~g}$ yeast extract, $10 \mathrm{~g}$ peptone, $100 \mathrm{mM}$ potassium phosphate buffer $\mathrm{pH}$ 6.0, $13.4 \mathrm{~g}$ yeast nitrogen base with ammonium 
sulfate, $0.4 \mathrm{mg}$ biotin) and incubated at $30^{\circ} \mathrm{C}$ at vigorous shaking. After $24 \mathrm{~h}, 1 \mathrm{~mL}$ of these cultures was transferred into fresh $25 \mathrm{~mL}$ of main culture medium, and incubated again at $30^{\circ} \mathrm{C}$ at vigorous shaking for $6.5 \mathrm{~h}$ to retain the cells in exponential growth phase, before cells were harvested by centrifugation at $10000 \times \mathrm{g}$ for $6 \mathrm{~min}$ at $4{ }^{\circ} \mathrm{C}$. The pellet was stored at $-70^{\circ} \mathrm{C}$ immediately.

\section{Chemostat cultivations}

The chemostat cultivations were performed in a $2.0 \mathrm{~L}$ working volume bioreactor (MBR, Wetzikon, Switzerland) with a computer based process control (ISE, Vienna, Austria) as described in [41].

A shake flask containing $100 \mathrm{~mL}$ of YPG medium (per liter: 10 g yeast extract, $10 \mathrm{~g}$ peptone, $10 \mathrm{~g}$ glycerol) was inoculated with one $1.8 \mathrm{~mL}$ cryovial of the $P$. pastoris cell bank, and incubated at $28^{\circ} \mathrm{C}$ for approximately 24 hours with agitation at $180 \mathrm{rpm}$. This culture was used to inoculate the starting volume $(1.4 \mathrm{~L})$ of the bioreactor to an optical density (OD600) of 1.0.

Cultivation temperature was controlled either at $20^{\circ} \mathrm{C}$ or $25^{\circ} \mathrm{C}$, the $\mathrm{pH}$ was controlled at pH 5.0 with $25 \%$ ammonium hydroxide and the dissolved oxygen concentration was maintained above $20 \%$ saturation by controlling the stirrer speed between 600 and $1200 \mathrm{rpm}$, whereas the airflow was kept constant at $100 \mathrm{~L} \mathrm{~h}^{-1}$.

The media were as follows:

Batch medium contained per liter:

$2.0 \mathrm{~g}$ citric acid, $12.4 \mathrm{~g}\left(\mathrm{NH}_{4}\right)_{2} \mathrm{HPO}_{4}, 0.022 \mathrm{~g} \mathrm{CaCl}_{2}$. $2 \mathrm{H}_{2} \mathrm{O}, 0.9 \mathrm{~g} \mathrm{KCl}, 0.5 \mathrm{~g} \mathrm{MgSO}_{4} \cdot 7 \mathrm{H}_{2} \mathrm{O}, 40$ g glycerol, 4.6 $\mathrm{ml}$ PTM1 trace salts stock solution. The $\mathrm{pH}$ was set to 5.0 with $25 \% \mathrm{HCl}$.

Chemostat medium contained per liter:

55 g glucose $1 \mathrm{H}_{2} \mathrm{O}, 2.5 \mathrm{~g} \mathrm{KCl}, 1.0 \mathrm{~g} \mathrm{MgSO}_{4} \cdot 7 \mathrm{H}_{2} \mathrm{O}$,

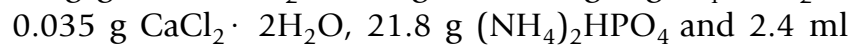
PTM1 trace salts stock solution; furthermore the $\mathrm{pH}$ was set to 5.0 with $25 \% \mathrm{HCl}$.

PTM1 trace salts stock solution contained per liter:

$6.0 \mathrm{~g} \mathrm{CuSO}_{4} \cdot 5 \mathrm{H}_{2} \mathrm{O}, 0.08 \mathrm{~g} \mathrm{NaI}, 3.0 \mathrm{~g} \mathrm{MnSO}_{4} \cdot \mathrm{H}_{2} \mathrm{O}, 0.2$ $\mathrm{g} \mathrm{Na}_{2} \mathrm{MoO}_{4} \cdot 2 \mathrm{H}_{2} \mathrm{O}, 0.02 \mathrm{~g} \mathrm{H}_{3} \mathrm{BO}_{3}, 0.5 \mathrm{~g} \mathrm{CoCl}_{2}, 20.0 \mathrm{~g}$ $\mathrm{ZnCl}_{2}, 65.0 \mathrm{~g} \mathrm{FeSO}_{4} \cdot 7 \mathrm{H}_{2} \mathrm{O}, 0.2 \mathrm{~g}$ biotin and $5.0 \mathrm{ml}$ $\mathrm{H}_{2} \mathrm{SO}_{4}$ (95\%-98\%). All chemicals for PTM1 trace salts stock solution were from Riedel-de Haën (Seelze, Germany), except for biotin (Sigma, St. Louis, MO, USA), and $\mathrm{H}_{2} \mathrm{SO}_{4}$ (Merck Eurolab).
After approximately 24 hours the batch was finished and a flow rate of $\mathrm{F}=60.0 \mathrm{~g} \mathrm{~h}^{-1}$ of the dilution pump as well as of the harvest pump was started to adjust a dilution rate of $\mathrm{D}=0.0429 \mathrm{~h}^{-1}$. The continuous fermentation was performed at least for 5 resident times $\tau$ to reach steady state conditions. Then the temperature was shifted to the other set point. Samples were taken after 3 and $5 \tau$ and analyzed as described below.

\section{Optical density}

The samples were diluted in $\mathrm{ddH}_{2} \mathrm{O}$ up to 1:500 to measure the OD at $600 \mathrm{~nm}$.

\section{Biomass determination}

$2 \times 5 \mathrm{ml}$ culture were collected by centrifugation and the supernatants frozen for further analysis. The pellets were washed in $\mathrm{ddH}_{2} \mathrm{O}$, centrifuged again, then the pellets were resuspended in $\mathrm{ddH}_{2} \mathrm{O}$, transferred to a weighed beaker, dried at $105^{\circ} \mathrm{C}$ until constant weight.

\section{Quantification of Fab (ELISA)}

To determine the Fab content, 96 well microtiter plates (MaxiSorb, Nunc, Denmark) were coated with anti-hIgG (Fab specific) overnight at RT (1:1000 in PBS, pH 7.4), before serially diluted supernatants of $P$. pastoris cultures secreting 2F5 Fab starting with a 1:100 dilution in dilution buffer (PBS adjusted to pH 7.4 containing $0.1 \%$ Tween 20 and $1 \%$ BSA) were applied and incubated for $2 \mathrm{~h}$ at RT. Fab of normal IgG (Rockland Biopharmaceuticals) was used as a standard protein at a starting concentration of $200 \mathrm{ng} / \mathrm{mL}$. After each incubation step the plates were washed four times with PBS containing 1\% Tween 20 adjusted to $\mathrm{pH}$ 7.4. $100 \mu \mathrm{L}$ of anti-kappa light chain - AP conjugate as secondary antibody (1:1000 in dilution buffer) were added to each well, and incubated for $1 \mathrm{~h}$ at RT. After washing, the plates were stained with pNPP (1 $\mathrm{mg} / \mathrm{ml}$ p-nitrophenyl phosphate in coating buffer, $0.1 \mathrm{~N}$ $\mathrm{Na}_{2} \mathrm{CO}_{3} / \mathrm{NaHCO}_{3} ; \mathrm{pH} 9.6$ ) and read at $405 \mathrm{~nm}$ (reference wavelength $620 \mathrm{~nm}$ ).

\section{Immunofluorescent staining}

Ethanol fixation and immunofluorescent staining were performed as described by [42]. Briefly, fixed cells were washed, blocked in Tris buffer containing $0.1 \%$ Triton X100 and $2 \%$ BSA (both Sigma) and incubated in $200 \mu \mathrm{l}$ of this buffer and goat anti-hIgG (Fab specific) or goat anti-kappa light chain (both antibodies were applied as FITC conjugates and diluted 1:100). For the detection of intracellular BiP, rabbit anti-Grp78 (StressGen, Vancouver, BC, Canada) was used as described above. Anti-rabbit IgG - FITC conjugate (diluted 1:100) was used as secondary antibody. Finally cells were centrifuged and resuspended in $200 \mu \mathrm{l}$ PBS, pH 7.4. 


\section{FCM measurements}

Cells were analysed on a FACS Calibur (Becton Dickinson, Franklin Lakes, NJ USA) with a $488 \mathrm{~nm}$ Argon laser and a $630 \mathrm{~nm}$ diode laser. $10^{4}$ cells were measured per analysis, using PBS as the sheath fluid. Immunofluorescent staining as well as total protein staining with FITC were measured through a 530/30 BP filter (FL1). Threshold settings were adjusted so that cell debris was excluded from data aquisition.

Immunofluorescence data were normalized to the cell size by dividing the FL1 fluorescence signals by their respective volume-corrected forward scatter signals (FSC) as illustrated in equation (1) [42], and calculating the median of these ratios.

$$
\text { rel.fluorescence }=\frac{F L 1}{F S C\left(\frac{3}{2}\right)}
$$

\section{RNA isolation}

The frozen cell pellet was resuspended in $1 \mathrm{~mL}$ of TRIzol (Invitrogen) and $500 \mu \mathrm{L}$ of acid washed glass beads (425$600 \mu \mathrm{M}$ diameters, Sigma) were added. Cells were disrupted with a FastPrep cell homogenizer (Thermo, Germany) using $6 \mathrm{~m} / \mathrm{s}$ for $2 \times 30 \mathrm{~s}$ and chilling the cells on ice inbetween. Total RNA was then extracted following the TRI protocol provided by the supplier. Extracted RNA was quantified by measuring OD230/260/280, as well as with the RiboGreen RNA quantitation kit (Invitogen). RNA integrity was checked with the Agilent Bioanalyzer and RNA 6000 Nano Assay kit (Agilent Technologies, California).

PolyA RNA concentration in the extracted total RNA samples was determined with the TRAC protocol described below without the addition of the specific detection probes, and measured with the RiboGreen RNA quantitation kit (Invitrogen).

\section{Oligonucleotide detection probes}

The transcript levels of 55 genes have been chosen as markers, with a great emphasis on folding/secretion related genes as well as general physiological markers. Apart from literature [21], our selection was based on previous microarray experiments [43]. The $P$. pastoris genome sequence data was derived from the ERGO database (Integrated Genomics, Chicago; IL), and the sequences of the gene specific probes are shown in Table 4.

$P$. pastoris specific oligonucleotide probes were designed by using mathematical algorithms presented in [44]. Criteria used in probe selection were the following: melting temperature, $\mathrm{T}_{\mathrm{m}^{\prime}}$ limits $60-70^{\circ} \mathrm{C}, \mathrm{GC} \%$ limits $38-62$, maximum free energy change in hybridisation $\Delta \mathrm{G}_{\mathrm{H}}>-15$ $\mathrm{kcal} / \mathrm{mol}[45]$ and minimum target energy change, $\mathrm{A}_{\mathrm{c}^{\prime}}<-$ $10 \mathrm{kcal} / \mathrm{mol}$ [46]. A maximum repeat size of $15 \mathrm{nt}$ and maximum similarity of $80 \%$ were used as probe specificity criteria. $\mathrm{T}_{\mathrm{m}} \mathrm{s}$ were calculated with the nearest neighbour method according to le Novére [45] using $10 \mathrm{nM}$ nucleic acid and $750 \mathrm{mM}$ salt concentrations. The double 6-carboxy fluorescein (6-FAM) labelled oligonucleotides were synthesized by Metabion (Germany).

As the hybridised probes were distinguished from each other based on their different size (ranging from 25 to 45 nucleotides), they had to be assigned into 5 pools such that the probes in the same pool have unique sizes different enough from each other. Quantification of transcript level was according to fluorescence intensity of the respective probes after standardisation.

\section{TRAC}

For the transcriptional profiling, the rapid assay for multiplex transcript analysis based on solution hybridisation of oligonucleotide probes to target mRNA called TRAC presented in [14] was established for P. pastoris. Basically, target mRNAs are hybridized with a probe pool consisting of gene-specific oligonucleotide probes with double fluorophore label and biotinylated oligo (dT) and captured on streptavidin-coated magnetic particles. After removal of unbound material, the specific probes are eluted and detected by capillary electrophoresis.

Total RNA corresponding to $100 \mathrm{ng}$ of polyA RNA were hybridized with 4pmol biotinylated oligo (dT) capture probe (Promega) and 1 pmol of each 6-FAM labelled detection probe in hybridisation buffer containing $5 \times$ SSC, $0.2 \%(\mathrm{w} / \mathrm{v}) \mathrm{SDS}, 1 \times$ Denhardt solution $(0.02 \%$ Ficoll, $0.02 \%$ polyvinyl pyrrolidone, $0.02 \%$ BSA) and $3 \%$ dextran sulphate. After $40 \mathrm{~min}$ of incubation at $60^{\circ} \mathrm{C}$, the $100 \mu \mathrm{L}$ hybridisation reactions were transferred to a KingFisher 96 magnetic bead particle processor (Thermo Electron) and the following steps of affinity capture, washing and elution were automated in 96-well plates. Alternatively, these steps were performed manually with a 96 well magnetic stand (Promega) and a multichannel pipette (Eppendorf) for one of the temperature shift chemostats.

Affinity capture of the hybridized mRNA targets to $50 \mu \mathrm{g}$ of streptavidin-coated MyOne Dynabeads (Invitrogen) was followed by several washing steps with decreasing salt concentration to remove unbound material. Briefly, the magnetic beads were washed twice with $1 \times$ SSC, $0.1 \%$ SDS for $1.5 \mathrm{~min}$ each, then twice with $0.5 \times$ SSC, $0.1 \%$ SDS and finally with $0.1 \times$ SSC, $0.1 \%$ SDS once (using 150 $\mu \mathrm{L}$ of the respective washing solution per well). The oligonucleotide probes were eluted to $10 \mu \mathrm{L}$ of HighFidelity formamide (Applied Biosystems) containing GeneScan- 
Table 4: Marker genes used in TRAC analysis.

\begin{tabular}{|c|c|c|c|c|c|c|c|}
\hline $\begin{array}{l}\text { Probe } \\
\text { name }\end{array}$ & Gene & $\begin{array}{l}\text { Location of the } \\
\text { probe in CDS }\end{array}$ & $\begin{array}{c}\text { Probe } \\
\text { length } \\
\text { (nt) }\end{array}$ & $\operatorname{Tm}\left({ }^{\circ} \mathrm{C}\right)$ & GC\% & Probe Sequence 5'-3' & Pool \\
\hline ACSI & ERGO:RPPA07570 & $893-917$ & 25 & 65.2 & 48.0 & TACTTGGTGGTCAAAAGAGCTCCCA & 1 \\
\hline SSEI/2 & ERGO:RPPAI0049 & $538-564$ & 27 & 63.7 & 44.4 & TTTGACGAGCTTCTCAACTGTCCTGTA & 1 \\
\hline VPSI7 & ERGO:RPPA07986 & $|583-161|$ & 29 & 64.2 & 44.8 & ACCTGCAGACTGGGTGCTAACTTTTTTCT & 1 \\
\hline LC & 2F5Fab_light_chain & $409-439$ & 31 & 65.6 & 41.9 & GTACTTTGGCCTCTCTGGGATAGAAGTTATT & 1 \\
\hline RPL3 & ERGO:RPPA07957 & $489-521$ & 33 & 64.9 & 45.5 & TTTTGGTTCAAAGGGGTCTTTCTGATCTGGGTG & 1 \\
\hline SEC6I & ERGO:RPPA04I 32 & $848-882$ & 35 & 65.4 & 40.0 & CATGATTGGCATGTTGGATGTGTAGAACAATCTGA & 1 \\
\hline PDII & ERGO:RPPA04694 & $768-804$ & 37 & 64.3 & 40.5 & GGCTAAAGGGATGTTAGCTTCAGCATATGATTTGAAG & 1 \\
\hline TRRI & ERGO:RPPA0620I & $815-853$ & 39 & 66.4 & 46.2 & CGAAAACACCTGGAATAGATGTAAGGGAAGAACCTGGGA & 1 \\
\hline RIBI & ERGO:RPPA08084 & $756-796$ & 41 & 66 & 39.0 & AAGAACGTTTGTCTGCTGGGTGTCTTAGTAAAAGATTTGCT & 1 \\
\hline TKLI & ERGO:RPPA06932 & $1782-1824$ & 43 & 67.5 & 39.5 & TATTGGAACACCGTCTGGAAGGACTGATAATTGGTAAGATCTA & 1 \\
\hline ARGI & ERGO:RPPA07954 & $813-857$ & 45 & 70.1 & 44.4 & GTCAAACCTGGAGTTTCATAACAACCTCTGGACTTGATTCCGATG & 1 \\
\hline $\mathrm{SNZ3/2}$ & ERGO:RPPAI0229 & $557-581$ & 25 & 63.3 & 44.0 & ATGGCAGCAGCTATCTTTTCAGGAT & 2 \\
\hline PMT6 & ERGO:RPPA04967 & $1054-1080$ & 27 & 62.8 & 44.4 & GTAATCTGTTGTTGGCTGGAACCTTGA & 2 \\
\hline GCN4 & ERGO:RPPA07905 & $359-387$ & 29 & 67.1 & 48.3 & AACGGCTGGAGTGGTAGCAAGAGTAGTTT & 2 \\
\hline SSA4 & ERGO:RPPAI065I & $1605-1635$ & 31 & 65.9 & 45.2 & CATATGATTCCAAGCCATTCTTGGCAGCAAC & 2 \\
\hline $\mathrm{HC}$ & 2F5Fab_heavy_chain & $669-701$ & 33 & 67.9 & 48.5 & GATTTGGGCTCAACTTTCTTGTCCACCTTGGTG & 2 \\
\hline KAR2 & ERGO:RPPA06939 & $1325-1359$ & 35 & 65 & 40.0 & AGTTGGGATAGCAGTGTTTCTGTTGATTAAGGTAG & 2 \\
\hline SEC53 & ERGO:RPPA08162 & $349-385$ & 37 & 63.8 & 40.5 & CGTTTCTGAACTCAATGAATGTTCCTCTTCTGATTGG & 2 \\
\hline IMHI & ERGO:RPPA04985 & $1949-1987$ & 39 & 62.4 & 38.5 & TGTCTTTTTCCAATTCATCTCGTTTGGAGAGGACTAAAG & 2 \\
\hline BFR2 & ERGO:RPPA04523 & $700-740$ & 41 & 65.8 & 39.0 & AACTCTTGGCTCACAATCTTGCTTTTGTTTAATAGCTTGCC & 2 \\
\hline SEC3I & ERGO:RPPA062II & $1243-1285$ & 43 & 70 & 44.2 & TTTCGTCGACAAGAGTTTGGTAATCGTTTGTGCTGATGGTGCT & 2 \\
\hline HSP90/82 & ERGO:RPPA05876 & $891-915$ & 25 & 63.9 & 48.0 & CTTAACAGCCAATGGGTCTTCCCAA & 3 \\
\hline ARO4 & ERGO:RPPA09892 & $786-812$ & 27 & 62.8 & 44.4 & TTTCCGTGGGAACAGTCAATCATCAGA & 3 \\
\hline EROI & ERGO:RPPA06II5 & $|53|-1559$ & 29 & 64.4 & 44.8 & TCTCGGTGCCTTTGAGTGCCAATGAAAAT & 3 \\
\hline TALI & ERGO:RPPA08309 & $550-580$ & 31 & 63.5 & 41.9 & CCTTGTACCAGTCAAGAATACGTCCAACAAA & 3 \\
\hline $\mathrm{BMH} 2$ & ERGO:RPPA07I90 & $546-578$ & 33 & 66.1 & 48.5 & AAATGACAGGCGCGGTCAGGAGAGTTTAGAATC & 3 \\
\hline ROT2 & ERGO:RPPA08267 & $1634-1668$ & 35 & 63.3 & 40.0 & ATACGACCTAGTAAGAACAAATGGCCTATGGTTTG & 3 \\
\hline GLRI & ERGO:RPPA07699 & $965-1001$ & 37 & 67.7 & 45.9 & CTGTTAGATAGTTTTCTACCAGCAGCGATTGCGACAG & 3 \\
\hline RADI6 & ERGO:RPPA09210 & $1007-1045$ & 39 & 63.6 & 38.5 & TATTGTGGGCTTCGTCTAAAATGACCCTATAAAAATGCG & 3 \\
\hline GSH2 & ERGO:RPPA06484 & $949-989$ & 41 & 61.8 & 39.0 & AGAATTTGTTGAACTTTTTTACAACCGCTAAGCTGGGTCAG & 3 \\
\hline RAD2 & ERGO:RPPA08434 & $36 I-403$ & 43 & 65.8 & 39.5 & CTTGGGTAACCTCATCCGAATCTCTTTGGTCTTTTTTATGTTG & 3 \\
\hline CNEI & ERGO:RPPA04260 & 749-793 & 45 & 69.9 & 42.2 & GGATGTACAATTCAGCATCTTCGTTCCAGTTTTCTGGTTTCACAG & 3 \\
\hline HOGI & ERGO:RPPA06104 & $581-605$ & 25 & 67.8 & 56.0 & TCATCTCGGCGAAAATGCACCCTGC & 4 \\
\hline SECI8 & ERGO:RPPA05I 38 & $1027-1053$ & 27 & 63.5 & 40.7 & TACCAATATCCAGCTTGTTGGTACCAA & 4 \\
\hline CUP5 & ERGO:RPPA08088 & $|23-15|$ & 29 & 63.3 & 41.4 & СACTGTATTCTTGATCAGTAAGTCTGGAC & 4 \\
\hline SARI & ERGO:RPPA0844I & $475-505$ & 31 & 62.9 & 38.7 & CCTGTCTTAAGTAGATAGAGCAGGTAAATAC & 4 \\
\hline ARL3 & ERGO:RPPA09566 & $336-368$ & 33 & 62.5 & 42.4 & AACGTCCTGTTTATTGGCAAGCATAAGAATCGG & 4 \\
\hline DFMI & ERGO:RPPAI 0235 & $824-860$ & 37 & 63.1 & 40.5 & CATTTCTTATCGCAGTAGCTTGGTTTTTCCGTCTTTG & 4 \\
\hline HEMI2 & ERGO:RPPA08255 & $816-852$ & 37 & 63.1 & 40.5 & TGGACGGAATAACCAATCCAACGAGACAACATCATAA & 4 \\
\hline RAD54 & ERGO:RPPA0432I & $2193-2231$ & 39 & 63.9 & 38.5 & ACACATGAACTCAATTGCAGTTTAGCTGATTGTCTTTGG & 4 \\
\hline RPS23B & ERGO:RPPA09269 & $187-227$ & 41 & 66.2 & 41.5 & AACTGAACTCTGACACACTTTCTAATAGCGGAGTTAGGTTG & 4 \\
\hline MSN2 & ERGO:RPPA05326 & $985-1027$ & 43 & 70.5 & 41.9 & GCTCATTCGTGTCTATGGACTTTGCCCTCTTTCTTTGTTTTGT & 4 \\
\hline SSO2 & ERGO:RPPA06663 & $356-400$ & 45 & 71.4 & 40.0 & GCTGTTCTCTGTAGTTGCTTTCAATAATACGGTAGTCCTGAATAG & 4 \\
\hline GLTI & ERGO:RPPA07339 & $1740-1764$ & 25 & 63.4 & 48.0 & CACAATCGATTCCCTGATGGGATCA & 5 \\
\hline UBCI & ERGO:RPPA0958I & $273-299$ & 27 & 64.4 & 44.4 & AGAATAGGCGTCCAGGCATTCTTCAAT & 5 \\
\hline HSPI2 & ERGO:RPPA05227 & $211-239$ & 29 & 64.8 & 44.8 & TGAACTTGCTCAACTAAGGTAGGTTGGGT & 5 \\
\hline PFKI & ERGO:RPPA04I64 & $2447-2479$ & 33 & 63.4 & 39.4 & TTTTACCCGATTTGTTCTTACCATCGTCTTCCT & 5 \\
\hline CITI & ERGO:RPPAI 0025 & $758-792$ & 35 & 67.1 & 40.0 & GATAGACAGGTATAATCTCATCAGCTCAACGAACT & 5 \\
\hline HRDI & ERGO:RPPA05I58 & $1188-1222$ & 35 & 63.8 & 42.9 & TGAAGGAATTATCGGAATTGGACTGCAGTGGGAAT & 5 \\
\hline $\mathrm{SNCl}$ & ERGO:RPPA04520 & $275-313$ & 39 & 63.9 & 41.0 & AGGAACGATGATAACAATCAGCAAAATCACGATTCCCAG & 5 \\
\hline KIN2 & ERGO:RPPA04639 & $640-680$ & $4 I$ & 70.6 & 43.9 & TTTACGGTTGCATCGTAGTCATCAAATTCTGTCCCGTCAAG & 5 \\
\hline TSAI & ERGO:RPPA06990 & $540-582$ & 43 & 66.5 & 44.2 & GGACTTGGAAAAGAATTCCTTGGAAGCATCAACTTCTGGCTTG & 5 \\
\hline CPR5 & ERGO:RPPA09912 & $314-358$ & 45 & 71.9 & 42.2 & TGAAGTTCTCGTCCTTGAATCTGCTACCGTAGATAGATTTTCCTC & 5 \\
\hline
\end{tabular}

The $P$. pastoris specific probes designed for TRAC, divided into five pools according to their migration in capillary electrophoresis. Location of the probe in the coding sequence (CDS) is indicated. All oligonucleotides are labelled with 6-FAM at $3^{\prime}$ and $5^{\prime}$ ends.

120 LIZ size standard (diluted 1:500, Applied Biosystems) for $20 \mathrm{~min}$ at $37^{\circ} \mathrm{C}$.

Separation and analysis of the oligonucleotide probes was carried out by capillary electrophoresis with an ABI 3100
Genetic Analyser (Applied Biosystems) and the GeneMapper software.

The individual probes were identified by their migration time (compared to the GeneScan LIZ-120 size standard), 
and quantified by their peak area. Quantification of transcript level was according to fluorescence intensity of the respective probes after standardisation with signal of the internal standard.

\section{Internal standard}

E. coli traT RNA was used as an internal standard in the hybridisations. The following PCR primers (Metabion, Martinsried, Germany) were used to synthesise, from E. coli DNA, a template containing the $\mathrm{T} 7$ promoter sequence and a $25 \mathrm{nt}$ long T tail: 5' CTAATACGACTCACTATAGGGAGA-ATGAAAAAATTGATGATGGT and 3' TTTTTTTTTTTTTTTTTTTTTTTTT-CAGAGTGCGATT-

GATTTGGC. The traT RNA was transcribed in vitro by T7RNA polymerase from this template, using the MEGAscript transcription kit (Ambion, Austin, TX) as recommended by the manufacturer. The synthesized traT RNA was quantified by Agilent Bioanalyser and RiboGreen RNA quantitation kit (Molecular Probes, Leiden, The Netherlands) as recommended by the manufacturer.

To enable the comparison of different samples equal amounts of in vitro transcribed bacterial RNA was added to each sample before the hybridisation, and its respective 6-FAM labelled detection probe was present in each individual probe pool.

\section{Statistical data evaluation}

The relative expression levels given here are based on fluorescence intensity per ng polyA RNA (FL).

TRAC analysis was performed in duplicates for each sample. Variation between these duplicate assays was analysed to calculate a method specific variation $\left(S_{M V}\right)$. Additionally, for the temperature experiments, the variation between the two biological replicas, and the different labs (VTT Finland and IAM Vienna) where the TRAC measurements were performed, was determined $\left(S_{B V}\right)$. The overall variation $\left(S_{A}\right)$ was estimated by the incorporation of error propagation according to the equation (2) of Gauß:

$$
s_{A}=\sqrt{s_{M V}^{2}+s_{B V}^{2}} .
$$

For the temperature experiments, the ratio of the FL in $20^{\circ} \mathrm{C}$ steady state to the FL in $25^{\circ} \mathrm{C}$ steady state samples was calculated individually for each of the two biological replicas. A Student t-test was performed to assess the probability ( $p$ values) that the FL $20^{\circ} \mathrm{C}$ does actually differ significantly from FL $25^{\circ} \mathrm{C}$ for each marker gene. Finally the mean ratio of the biological replicas was calculated for each probe and a Chi square $\left(\chi^{2}\right)$-test was performed to combine the individual probabilities obtained from the two independent measurements. The formula is displayed in equation (3), and is based on $2 \mathrm{k}$ degrees of freedom, where $\mathrm{k}$ is the number of probabilities being combined. The procedure of significance testing was repeated for each gene.

$$
\chi^{2}=-2 \cdot \sum \ln (p)
$$

Significant regulation was defined by the ratios being \pm one, two or three times the overall standard deviation $S_{A}$. Simultaneously the significance of FL $20^{\circ} \mathrm{C}$ being different from FL $25^{\circ} \mathrm{C}$ was evaluated based on the $\chi^{2}$ distribution resulting in the combined $p$ values of the individual t-tests. Each of these two different criteria defines significance based on a different statistical test.

Estimation of the overall variance distributes the variance to all measurements, so that the probability of false negatives increases. To circumvent this problem, the significance of regulations at the single gene level was additionally determined with a t-test. Significant regulation is given if at least one of these criteria is valid. The combined individual probabilities of the two independent chemostat cultivations computed with a $\chi^{2}$-test (equation (3)) are stated in Figure 4 along with the mean ratio for each individual marker gene.

\section{Authors' contributions}

BG carried out the TRAC analysis, all data analysis and drafted the manuscript. MM designed and carried out all bioreactor cultivations. JR participated in the computer based design of the TRAC probes and data analysis. MiS participated in selection of the marker genes and design of the study. $\mathrm{AB}$ was involved in annotation of the P. pastoris genome. MaS participated in selection of the marker genes and design of the study. MP participated in the conception of the study. DM conceived of the study, and participated in statistical analysis and drafting of the manuscript.

\section{Acknowledgements}

Brigitte Gasser has been awarded a FEMS Research Fellowship to support her stay at VTT in Finland.

Part of this work was supported by the Austrian Science Fund (project No. I37-B03), the European Science Foundation (programme EuroSCOPE), and the Austrian Research Promotion Agency (programme FHplus).

\section{References}

I. Cereghino JL, Cregg JM: Heterologous protein expression in the methylotrophic yeast Pichia pastoris. FEMS Microbiol Rev 2000, 24(I):45-66.

2. Macauley-Patrick S, Fazenda ML, McNeil B, Harvey LM: Heterologous protein production using the Pichia pastoris expression system. Yeast 2005, 22(4):249-270.

3. Mattanovich D, Gasser B, Hohenblum $H$, Sauer M: Stress in recombinant protein producing yeasts. I Biotechnol 2004, II3(I3): $121-135$.

4. Hohenblum H, Gasser B, Maurer M, Borth N, Mattanovich D: Effects of gene dosage, promoters, and substrates on unfolded protein stress of recombinant Pichia pastoris. Biotechnol Bioeng 2004, 85(4):367-375. 
5. Marx H, Sauer M, Resina D, Vai M, Porro D, Valero F, Ferrer P, Mattanovich $\mathrm{D}$ : Cloning, disruption and protein secretory phenotype of the GASI homologue of Pichia pastoris. FEMS Microbiol Lett 2006, 264(I):40-47.

6. Resina D, Cos O, Ferrer P, Valero F: Developing high cell density fed-batch cultivation strategies for heterologous protein production in Pichia pastoris using the nitrogen source-regulated FLD I Promoter. Biotechnol Bioeng 2005, 9 I(6):760-767.

7. Gasser B, Maurer M, Gach J, Kunert R, Mattanovich D: Engineering of Pichia pastoris for improved production of antibody fragments. Biotechnol Bioeng 2006, 94(2):353-36I

8. Gach JS, Maurer M, Hahn R, Gasser B, Mattanovich D, Katinger H, Kunert R: High level expression of a promising anti-idiotypic antibody fragment vaccine against HIV-I in Pichia pastoris. Biotechnol 2007, I 28(4):735-746.

9. Ma Y, Hendershot LM: The unfolding tale of the unfolded protein response. Cell 200I, I 07(7):827-830.

10. $\mathrm{Ma} \mathrm{Y}$, Hendershot LM: ER chaperone functions during norma and stress conditions. J Chem Neuroanat 2004, 28( I-2):5 I-65.

II. Patil C, Walter P: Intracellular signaling from the endoplasmic reticulum to the nucleus: the unfolded protein response in yeast and mammals. Curr Opin Cell Biol 200I, I 3(3):349-355.

12. Valkonen $M$, Penttilä $M$, Saloheimo $M$ : Effects of inactivation and constitutive expression of the unfolded- protein response pathway on protein production in the yeast Saccharomyces cerevisiae. Appl Environ Microbiol 2003, 69(4):2065-2072.

13. Valkonen M, Ward M, Wang H, Penttila M, Saloheimo M: Improvement of foreign-protein production in Aspergillus niger var. awamori by constitutive induction of the unfolded-protein response. Appl Environ Microbiol 2003, 69(1 2):6979-6986.

14. Rautio J], Kataja K, Satokari R, Penttila M, Soderlund H, Saloheimo M Rapid and multiplexed transcript analysis of microbial cultures using capillary electophoresis-detectable oligonucleotide probe pools. J Microbiol Methods 2006, 65(3):404-4l6.

15. Rautio J, Smit BA, Wiebe M, Penttila M, Saloheimo M: Transcriptional monitoring of steady state and effects of anaerobic phases in chemostat cultures of the filamentous fungus Trichoderma reesei. BMC Genomics 2006, 7:247.

16. Li Z, Xiong F, Lin Q, d'Anjou M, Daugulis AJ, Yang DS, Hew CL: Lowtemperature increases the yield of biologically active herring antifreeze protein in Pichia pastoris. Protein Expr Purif 200I, 2 I (3):438-445.

17. Jahic M, Gustavsson M, Jansen AK, Martinelle M, Enfors SO: Analysis and control of proteolysis of a fusion protein in Pichia pastoris fed-batch processes. I Biotechnol 2003, I 02(I):45-53.

18. Integrated Genomics: ERGO bioinformatics suite. [http:// ergo.integratedgenomics.com/ERGO/].

19. Overbeek R, Larsen N, Walunas T, D'Souza M, Pusch G, Selkov E Jr Liolios K, Joukov V, Kaznadzey D, Anderson I, Bhattacharyya A, Burd H, Gardner W, Hanke P, Kapatral V, Mikhailova N, Vasieva O, Osterman A, Vonstein V, Fonstein M, Ivanova N, Kyrpides N: The ERGO genome analysis and discovery system. Nucleic Acids Res 2003, 3I(I):|64-|7|.

20. project SGD: Saccharomyces Genome Database. [http:// www.yeastgenome.org/]

21. Travers KJ, Patil CK, Wodicka L, Lockhart DJ, Weissman JS, Walter $P$ : Functional and genomic analyses reveal an essential coordination between the unfolded protein response and ERassociated degradation. Cell 2000, I 0 I (3):249-258.

22. Arvas M, Pakula T, Lanthaler K, Saloheimo M, Valkonen M, Suortti T, Robson G, Penttila M: Common features and interesting differences in transcriptional responses to secretion stress in the fungi Trichoderma reesei and Saccharomyces cerevisiae. BMC Genomics 2006, 7:32

23. Patil CK, Li H, Walter P: Gcn4p and novel upstream activating sequences regulate targets of the unfolded protein response. PLoS Biol 2004, 2(8):E246.

24. Harding HP, Zhang Y, Zeng H, Novoa I, Lu PD, Calfon M, Sadri N, Yun C, Popko B, Paules R, Stojdl DF, Bell JC, Hettmann T, Leiden JM, Ron $D$ : An integrated stress response regulates amino acid metabolism and resistance to oxidative stress. Mol Cell 2003, I I (3):619-33.

25. Causton HC, Ren B, Koh SS, Harbison CT, Kanin E, Jennings EG, Lee TI, True HL, Lander ES, Young RA: Remodeling of yeast genome expression in response to environmental changes. Mol Biol Cell 200I, I 2(2):323-337.
26. Rodriguez-Navarro S, Llorente $B$, Rodriguez-Manzaneque MT, Ramne A, Uber G, Marchesan D, Dujon B, Herrero E, Sunnerhagen P, PerezOrtin JE: Functional analysis of yeast gene families involved in metabolism of vitamins BI and B6. Yeast 2002, I9(14): | 26I-1276.

27. Gasch AP, Spellman PT, Kao CM, Carmel-Harel O, Eisen MB, Storz $G$, Botstein D, Brown PO: Genomic expression programs in the response of yeast cells to environmental changes. Mol Biol Cell 2000, I I ( I 2):424 I-4257.

28. Sims AH, Gent ME, Lanthaler K, Dunn-Coleman NS, Oliver SG, Robson GD: Transcriptome analysis of recombinant protein secretion by Aspergillus nidulans and the unfolded-protein response in vivo. Appl Environ Microbiol 2005, 7 I (5):2737-2747.

29. Xu P, Raden D, Doyle FJ 3rd, Robinson AS: Analysis of unfolded protein response during single-chain antibody expression in Saccaromyces cerevisiae reveals different roles for $\mathrm{BiP}$ and PDI in folding. Metab Eng 2005, 7(4):269-279.

30. Hackel BJ, Huang D, Bubolz JC, Wang XX, Shusta EV: Production of soluble and active transferrin receptor-targeting singlechain antibody using Saccharomyces cerevisiae. Pharm Res 2006, 23(4):790-797.

31. Werner ED, Brodsky JL, McCracken AA: Proteasome-dependent endoplasmic reticulum-associated protein degradation: an unconventional route to a familiar fate. Proc Natl Acad Sci U S A 1996, 93(24): I3797-1380|.

32. Brodsky JL, Werner ED, Dubas ME, Goeckeler JL, Kruse KB, McCracken AA: The requirement for molecular chaperones during endoplasmic reticulum-associated protein degradation demonstrates that protein export and import are mechanistically distinct. J Biol Chem I999, 274(6):3453-3460.

33. Taxis C, Hitt R, Park SH, Deak PM, Kostova Z, Wolf DH: Use of modular substrates demonstrates mechanistic diversity and reveals differences in chaperone requirement of ERAD. J Biol Chem 2003, 278(38):35903-359I3.

34. Tsukada M, Gallwitz D: Isolation and characterization of SYS genes from yeast, multicopy suppressors of the functional loss of the transport GTPase Ypt6p. J Cell Sci 1996, 109 ( Pt I 0):247|-248|

35. Panadero J, Pallotti C, Rodriguez-Vargas S, Randez-Gil F, Prieto JA: A downshift in temperature activates the high osmolarity glycerol (HOG) pathway, which determines freeze tolerance in Saccharomyces cerevisiae. J Biol Chem 2006, 28 I (8):4638-4645

36. Soto T, Beltran FF, Paredes V, Madrid M, Millar JB, Vicente-Soler J, Cansado J, Gacto $M$ : Cold induces stress-activated protein kinase-mediated response in the fission yeast Schizosaccharomyces pombe. Eur J Biochem 2002, 269(20):5056-5065.

37. Zhang L, Onda K, Imai R, Fukuda R, Horiuchi H, Ohta A: Growth temperature downshift induces antioxidant response in Saccharomyces cerevisiae. Biochem Biophys Res Commun 2003, 307(2):308-314.

38. O'Kane D, Gill V, Boyd P, Burdon R: Chilling, oxidative stress and antioxidant responses in Arabidopsis thaliana callus. Planta 1996, 198(3):37|-377.

39. Michelsen K, Mrowiec T, Duderstadt KE, Frey S, Minor DL, Mayer $\mathrm{MP}$, Schwappach B: A multimeric membrane protein reveals 14-3-3 isoform specificity in forward transport in yeast. Traffic 2006, 7(7):903-916.

40. Prakash S, Prakash L: Nucleotide excision repair in yeast. Mutat Res 2000, 45 I( I-2): | 3-24.

4I. Maurer M, Kuhleitner M, Gasser B, Mattanovich D: Versatile modeling and optimization of fed batch processes for the production of secreted heterologous proteins with Pichia pastoris. Microb Cell Fact 2006, 5:37.

42. Hohenblum $\mathrm{H}$, Borth $\mathrm{N}$, Mattanovich $\mathrm{D}$ : Assessing viability and cell-associated product of recombinant protein producing Pichia pastoris with flow cytometry. J Biotechnol 2003, I 02(3):281-290.

43. Sauer M, Branduardi P, Gasser B, Valli M, Maurer M, Porro D, Mattanovich D: Differential gene expression in recombinant Pichia pastoris analysed by heterologous DNA microarray hybridisation. Microb Cell Fact 2004, 3(I): 17.

44. Kivioja T, Arvas M, Kataja K, Penttila M, Soderlund H, Ukkonen E: Assigning probes into a small number of pools separable by electrophoresis. Bioinformatics 2002, I 8 SuppI I:SI99-206.

45. Le Novere N: MELTING, computing the melting temperature of nucleic acid duplex. Bioinformatics 200 I, I 7( I 2): I 226- I 227. 
46. Luebke KJ, Balog RP, Garner HR: Prioritized selection of oligodeoxyribonucleotide probes for efficient hybridization to RNA transcripts. Nucleic Acids Res 2003, 3 I (2):750-758.

47. $E B I-E M B L E B I: E P C l u s t$ - Clustering, visualization, and analysis. [http://ep.ebi.ac.uk/EP/EPCLUST/].

Publish with Bio Med Central and every scientist can read your work free of charge

"BioMed Central will be the most significant development for disseminating the results of biomedical research in our lifetime. " Sir Paul Nurse, Cancer Research UK

Your research papers will be:

- available free of charge to the entire biomedical community

- peer reviewed and published immediately upon acceptance

- cited in PubMed and archived on PubMed Central

- yours - you keep the copyright

Submit your manuscript here:

http://www.biomedcentral.com/info/publishing_adv.asp
BioMedcentral 